Saint Louis University School of Law

Scholarship Commons

All Faculty Scholarship

2004

\title{
Questions About the Efficiency of Employment Arbitration Agreements
}

Matthew T. Bodie

Saint Louis University School of Law

Follow this and additional works at: https://scholarship.law.slu.edu/faculty

Part of the Labor and Employment Law Commons

\section{Recommended Citation}

Bodie, Matthew T., Questions About the Efficiency of Employment Arbitration Agreements. Georgia Law Review, vol. 39, no. 1 (2004).

This Article is brought to you for free and open access by Scholarship Commons. It has been accepted for inclusion in All Faculty Scholarship by an authorized administrator of Scholarship Commons. For more information, please contact erika.cohn@slu.edu, ingah.daviscrawford@slu.edu. 


\title{
GEORGIA LAW REVIEW
}

\begin{tabular}{lll}
\hline \hline VOLUME 39 & FALL 2004 & NUMBER 1 \\
\hline \hline
\end{tabular}

\author{
ARTICLES
}

\section{QUESTIONS ABOUT THE EFFICIENCY OF EMPLOYMENT ARBITRATION AGREEMENTS}

\section{Matthew T. Bodie*}

I. INTRODUCTION $\ldots \ldots \ldots \ldots \ldots \ldots \ldots \ldots \ldots \ldots \ldots \ldots \ldots \ldots$

II. Modeling the Decision to Arbitrate $\ldots \ldots \ldots \ldots \ldots$

A. THE COST-BENEFIT ANALYSIS BEHIND THE

POSTDISPUTE ARBITRATION AGREEMENT $\ldots \ldots \ldots \ldots 9$

B. THE COST-BENEFIT ANALYSIS BEHIND THE

PREDISPUTE ARBITRATION AGREEMENT

* Associate Professor, Hofstra University School of Law. A.B., 1991, Princeton University; J.D., 1996, Harvard Law School. I would like to thank Grant Hayden, Rebecca HollanderBlumoff, Keith Hylton, Erik Lillquist, Scott Moss, Peter Spiro, and David Zaring for their invaluable comments. Thanks to Lissa Mascio for her research assistance. This Article is dedicated to the memory of Daniel Collins. 
C. BEHAVIORAL CONCERNS ABOUT THE

PREDISPUTE AGREEMENT ANALYSIS . . . . . . . . 31

1. Misconceptions and Probabilistic "Editing" ....... . 33

2. Certainty Bias . . . . . . . . . . . . . . . . 34

3. Optimism Bias ... . . . . . . . . . . . . 36

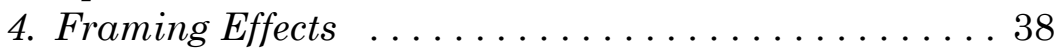

D. THE ADVANTAGES OF DEFERRING

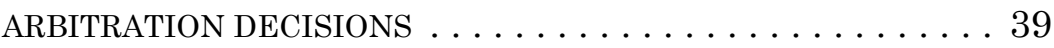

III. Potential Theories For the EfFiciency of

Predispute ARbitration AgreEments . . . . . . . . . . . 45

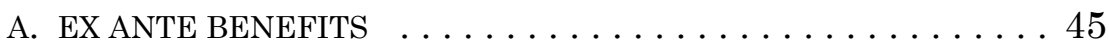

1. Spreading the Benefits .............. 46

2. Trading a Few Big Claims for Many Small Ones . . . 49

3. Eliminating or Reducing Precautionary Costs . . . . 54

4. Stronger Deterrence Through More

Accurate Adjudication ................. 57

5. Economies of Scale .................. . 59

B. PREVENTION OF IRRATIONAL POSTDISPUTE

ARBITRATION REJECTION . . . . . . . . . . . . . . . . 61

C. REDUCTION OF SOCIETAL EXTERNALITIES

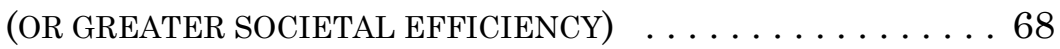

1. Diluting Employment Law Claims . . . . . . . 68

2. Reducing Societal Litigation Costs . . . . . . . . . 69

IV. Thoughts on the Next Generation of Debate $\ldots . . .744$

V. Conclusion ..................... 81 


\section{INTRODUCTION}

These days, it is hard to escape from arbitration agreements. Arbitration is not new; Congress passed the Federal Arbitration Act (FAA) in $1925^{1}$ to ensure that states would enforce arbitration agreements. $^{2}$ In the 1990s, however, the use of arbitration clauses in consumer and employment contracts exploded. ${ }^{3}$ Such agreements generally require that parties bring any common law or statutory claims arising out of the relationship to arbitration, rather than litigating such claims in court.

In Circuit City Stores, Inc. v. Adams, the Supreme Court resolved any lingering questions about the per se enforceability of arbitration agreements in the employment context. ${ }^{4}$ In the 1991 case Gilmer $v$. Interstate/Johnson Lane Corp., the Court had held that the FAA required the enforcement of an arbitration agreement between a securities analyst and his former employer, even as to the analyst's claim of age discrimination. ${ }^{5}$ The Gilmer arbitration agreement, however, was in a securities registration application, and the Court had not yet resolved whether the FAA applied to agreements set forth in employment contracts. ${ }^{6}$ In Circuit City, the Court held that the FAA required enforcement of arbitration agreements between almost all employers and employees with the sole exception of

Id.

1 Pub. L. No. 68-401, 43 Stat. 883 (1925) (codified as amended at 9 U.S.C. $§ 1-16(2000)$ ).

2 See 9 U.S.C. $\S 2(2000)$.

A written provision in any maritime transaction or a contract evidencing a transaction involving commerce to settle by arbitration a controversy thereafter arising out of such contract or transaction . . . shall be valid, irrevocable, and enforceable, save upon such grounds as exist at law or in equity for the revocation of any contract.

See Maureen A. Weston, Reexamining Arbitral Immunity in an Age of Mandatory and Professional Arbitration, 88 MINN. L. REV. 449, 449-50 (2004) (discussing explosive growth of arbitration cases administered by such arbitration groups as American Arbitration Association, National Arbitration Forum, and Judicial Arbitration and Mediation Services, Inc.).

4532 U.S. 105, 119 (2001).

5500 U.S. 20, 26-27 (1991).

${ }^{6}$ Id. at $25 \mathrm{n} .2$ ("Section 1 of the FAA provides that 'nothing herein contained shall apply to contracts of employment of seamen, railroad employees, or any other class of workers engaged in foreign or interstate commerce."”) (quoting 9 U.S.C. $\$ 1$ (2000)). The court declined to address the scope of the phrase "any other class of workers engaged in foreign or interstate commerce." Id. 
employees directly involved in interstate transportation. ${ }^{7}$ Ironically, Circuit City did not prevail in its own landmark decision. The Ninth Circuit denied enforcement of the arbitration agreement after concluding it was substantively and procedurally unconscionable. ${ }^{8}$

The history of the Circuit City case highlights an important shift in the discussion about employment arbitration agreements. Initially following Gilmer, commentators criticized the premise that employment arbitration agreements should be enforceable per se. ${ }^{9}$ A flurry of articles in the mid-1990s attacked the Gilmer premise, questioning whether arbitration could ever provide relief for violations of federal statutory rights, particularly antidiscrimination rights. ${ }^{10}$ However, the Court's analysis in Gilmer and Circuit City found that the FAA requires the general enforcement of arbitration agreements. ${ }^{11}$ The Court noted that the purpose of the FAA "was to place arbitration agreements on the same footing as other contracts." 12 Since the parties made an agreement to arbitrate, they "should be held to it." "13

\footnotetext{
7 Circuit City, 532 U.S. at 119 . The Court held that $\S 1$ of the FAA applied only to transportation workers' contracts of employment, namely, "those workers 'actually engaged in the movement of goods in interstate commerce.'" Id. at 112 (citation omitted). The purpose of this exclusion is somewhat unclear; as the Court noted in Circuit City, the legislative history of $\S 1$ is "quite sparse." Id. at 119.

8 Circuit City Stores, Inc. v. Adams, 279 F.3d 889, 896 (9th Cir. 2002).

9 See, e.g., Sarah Rudolph Cole, Incentives and Arbitration: The Case Against Enforcement of Executory Arbitration Agreements Between Employers and Employees, 64 UMKC L. REV. 449, 454 (1996) (arguing that courts should not enforce executory employment arbitration agreements); Katherine Van Wezel Stone, Mandatory Arbitration of Individual Employment Rights: The Yellow Dog Contract of the 1990s, 73 DENV. U. L. REv. 1017, 1019 (1996) (discussing trend toward mandatory arbitration at expense of workers' rights).

${ }_{10}$ See, e.g., Reginald Alleyne, Statutory Discrimination Claims: Rights "Waived" and Lost in the Arbitration Forum, 13 HofSTRA LAB. L.J. 381, 383-84 (1996) (arguing that arbitration in the employment context is "procedurally defective"); Joseph R. Grodin, Arbitration of Employment Discrimination Claims: Doctrine and Policy in the Wake of Gilmer, 14 HofsTRA LAB. L.J. 1, 52-53 (1996) (pointing out difficulty in adopting arbitration standards that promote fairness and public policy); Sharona Hoffman, Mandatory Arbitration: Alternative Dispute Resolution or Coercive Dispute Suppression?, 17 BERKELEY J. EMP. \& LAB. L. 131, 135 (1996) (arguing that mandatory arbitration agreements for employment disputes should not be enforced); Stone, supra note 9, at 1020 (arguing mandatory arbitration "threatens to deprive workers of their statutory rights").

11 Gilmer, 500 U.S. at 26-27; Circuit City, 532 U.S. at 119.

12 Gilmer, 500 U.S. at 33.

${ }^{13} I d$. at 26 (quoting Mitsubishi Motor Corp. v. Soler Chrysler-Plymouth, Inc., 473 U.S. $614,628(1985))$.
} 
The contract paradigm applied to arbitration agreements, however, does not require that every such agreement must be enforced. As the Court noted in Gilmer, an agreement to arbitrate may be unenforceable if such agreement "resulted from the sort of fraud or overwhelming economic power that would provide grounds 'for the revocation of any contract." "14 Thus, state and federal courts are now grappling with common-law contract doctrines as applied to particular employment arbitration agreements, with results such as the Ninth Circuit's determination in Circuit City that the agreement was unconscionable. ${ }^{15}$

The cornerstone presumption of contract law is that contracts are entered into freely by individuals who expect the contract to enhance their individual utility. Since rational actors would only agree to a contract if they believe the contract will make them better off, society can presume that each contract will enhance overall social welfare. ${ }^{16}$ If these presumptions do not hold true in the context of employment arbitration agreements, then a central justification for their enforcement would be inapplicable. We must therefore ask: Why are employees and employers making these agreements? Are these agreements being formed because each side believes it will be better off?

Using traditional law and economics models, influential commentators have argued that this must be the case. Simply stated, these scholars have found that arbitration agreements increase overall efficiency by allowing the parties to choose a more efficient method of dispute resolution. ${ }^{17}$ The purpose of this Article

14 Id. at 33 (quoting Mitsubishi Motor, 473 U.S. at 627).

15 Circuit City Stores, Inc. v. Adams, 279 F.3d 889, 892 (9th Cir. 2002); see also Alexander v. Anthony Int'l, 341 F.3d 256, 266-67 (3d Cir. 2003) (holding "take-it-or-leave-it" agreement procedurally unconscionable and limitation on employee relief substantively unconscionable); Morrison v. Circuit City Stores, Inc., 317 F.3d 646, 666-68 (6th Cir. 2003) (upholding arbitration agreement despite employee's arguments of unconscionability, lack of consideration, and insufficient bases for waiver); Brasington v. EMC Corp., 855 So. 2d 1212, 1217-18 (Fla. Dist. Ct. App. 2003) (finding arbitration agreement not procedurally unconscionable because employee had access to arbitration policy prior to signing).

16 EDWARD J. MURPhY ET AL., StUdiEs IN CONTRACT LAW 470 (6th ed. 2003).

17 See Keith N. Hylton, Agreements to Waive or to Arbitrate Legal Claims: An Economic Analysis, 8 SUP. Ст. ECON. REV. 209, 212-13 (2000) (discussing arbitration incentives where litigation is socially undesirable); Steven Shavell, Alternative Dispute Resolution: An Economic Analysis, 24 J. LEGAL STUD. 1, 8 (1995) (arguing that arbitration agreement enforcement increases social welfare). For this Article, I will use the term efficient in its broadest form: 
is to question this conclusion. In examining the law and economics of these agreements, I start by unpacking the considerations that go into the making of the agreements themselves. In creating a model of this decisionmaking process, I hope to show how economically rational employees and employers might go about making such decisions. This model sets forth the many factors an employee would need to know in order to make a rational economic decision about an arbitration agreement. The model also incorporates recent developments in the field of behavioral law and economics concerning systematic irrationalities that may influence the process. By trying to envision the actual decision to sign such agreements, I endeavor to establish a new starting point for debates about the wisdom of enforcing such agreements.

Part II establishes the basic economic model for agreements to arbitrate employment claims. I begin with a model for arbitration agreements that are executed after the claim has arisen-also known as postdispute arbitration agreements. After developing this model, I use it as the basis for a more complicated model for signing an agreement at the beginning of the employment relationship-a predispute arbitration agreement. As the model will demonstrate, the information necessary to determine the efficiency of a predispute agreement is likely to be unavailable to employees who contemplate such agreements. Faced with this dilemma, employees may fall back onto decisionmaking shortcuts, known as heuristics, which may lead them to an inefficient result. Thus, the cost-benefit analysis that employees can make about a postdispute agreement to arbitrate is more likely to be accurate, and thus more likely to produce an efficient result, than the analysis that employees can make about a predispute agreement.

Part III considers whether predispute employment arbitration agreements might still be efficient despite their underlying informational deficiencies. One possibility is that predispute

Efficient shall mean the result that provides for the greatest overall social utility. RICHARD A. POSNER, ECONOMIC ANALYSIS OF LAW 11-16 (6th ed. 2003). I differentiate general efficiency from Pareto efficiency in the usual manner: An efficient result is one in which the parties are better off overall, although an individual party may be worse off; whereas, all parties are better off when a result is Pareto efficient. See id. at 13-14 (comparing Pareto superiority with Kaldor-Hicks concept of efficiency). 
agreements provide some additional benefit by locking the parties in before the dispute has arisen. Another possibility is that employees will irrationally refrain from entering arbitration agreements after a dispute has arisen. A third possibility is that predispute agreements are more efficient because they reduce externalities such as judicial administration costs. Part IV sets forth some parameters for the next generation of debate.

\section{Modeling the Decision to ARBitrate}

Free exchange is the cornerstone of capitalism. Exchange is what allows individuals to maximize their utility, since individuals can specialize in producing one good or service but then acquire the panoply of other necessities through purchase or trade. Freedom of exchange through contract is the cornerstone of our commercial legal regime. The general rule in contracts is that people are free to agree to just about any type of exchange and have those agreements enforced in a court of law. ${ }^{18}$ The theory behind freedom of contract is simple: Parties will come to an agreement only if they believe that it is in their best interests to do so. Given that both parties think the agreement will improve their utility, people should be permitted to make such agreements and have them enforced in the future. ${ }^{19}$ Of course, some parties will change their mind about the costs and benefits of the bargain as the agreement plays out. Markets may rise and fall, and personal circumstances may change. Overall, however, society is better off if freely entered agreements are enforced. ${ }^{20}$

\footnotetext{
18 Exceptions to this general rule include contracts to commit a crime, surrogacy contracts, and waivers of certain statutory rights. E.g., RESTATEMENT (SECOND) OF CONTRACTS $§ 178$ (1978) (stating exception for contracts to commit a crime); In re Baby M, 537 A.2d 1227, 1250 (N.J. 1988) (voiding mother's contract to sell her surrogacy child); Alexander v. GardnerDenver Co., 415 U.S. 36, 51-52 (1974) (stating that employees cannot waive Title VII rights).

${ }_{19}$ See Eric A. Posner, Contract Law in the Welfare State: A Defense of the Unconscionability Doctrine, Usury Laws, and Related Limitations on the Freedom to Contract, 24 J. LEGAL STUD. 283, 284 (1995) ("In the area of contract law, the efficiency argument concludes that courts should enforce all voluntary contracts that do not produce negative externalities, regardless of their distributive consequences. If a contract is voluntary, then it presumptively improves the well-being of both parties.").

${ }^{20}$ For a discussion of other potential justifications for enforcing contracts, see Randy Barnett, A Consent Theory of Contract, 86 CoLuM. L. REV. 269, 271-91 (1986).
} 
Although freedom of contract is essential to our economic system, economic theory recognizes that freely formed contracts will not always be efficient. If parties knew exactly what the outcome of each contract would be, they would know the costs and benefits and would be able to determine each contract's relative efficiency. But parties do not always have perfect information, and parties may sometime be mistaken about the effect a contract will have on their social utility. The most obvious example of this phenomenon is fraud. When one party contracts to buy an authentic antique, his utility will be reduced if that "antique" is later discovered to be a clever knockoff. ${ }^{21}$ But parties often contract with incomplete and incorrect information, and they may not always choose an outcome that improves their utility. While contract law has delineated some such agreements as unenforceable,$^{22}$ there is no general principle that only efficient agreements will be enforced. Instead, our system presumes that parties will act rationally and will have sufficient information to make generally efficient decisions. ${ }^{23}$

Economists recognize, however, parties do not always have sufficient information. In fact, it is sometimes rational not to have such information; for example, the costs of obtaining this information could outweigh the benefits derived from the information. $^{24}$ If we know a certain type of contract will require information that will be systematically too costly to obtain, we may question whether such contracts actually do increase societal efficiency. In the face of incomplete information, parties may systematically fail to make efficient decisions about contracts, particularly if they do not recognize or identify this information failure.

For reasons discussed below, I believe that employment arbitration agreements are an example of contracts formed with cripplingly imperfect information. We can obtain insight into this possibility by modeling the actual decisions made by parties to

\footnotetext{
${ }^{21}$ See Posner, supra note 17, at 110-13 (distinguishing between lie and failure to

${ }^{22}$ For example, contract law allows parties to void some agreements on the basis of

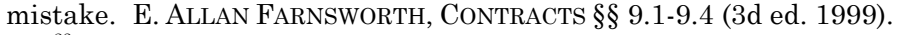

${ }^{23}$ See Posner, supra note 17, at 4 (discussing people as rational maximizers of self-

${ }^{24}$ Id. at 18.
} disclose). interest). 
execute these contracts. What follows is an effort to model the processes that inform decisions to arbitrate or litigate, both before and after disputes have arisen. I begin with the simpler model: the decision to arbitrate or litigate after the dispute has arisen.

\section{A. THE COST-BENEFIT ANALYSIS BEHIND THE POSTDISPUTE ARBITRATION} AGREEMENT

In our system of dispute resolution, litigation is the "default rule"-the result that will take place unless the parties agree to a different alternative. One possible alternative to litigation is arbitration. $^{25}$ The decision to take a legal dispute to arbitration, rather than to the court system, is one that a party will make only if he or she will be better off in arbitration. This decision can be made by weighing the costs and benefits of both options. ${ }^{26}$

The potential costs and benefits of litigation to the party bringing the suit are the expected relief that will be granted minus the costs of bringing the suit in the first place. The expected relief is the value of the likely damages (and other relief) discounted by the probability that the party will win the suit. The cost-benefit analysis of such a decision could be expressed as:

$$
P * R-C
$$

where $P$ is the probability of success, $R$ is the value of the expected relief, and $C$ is the cost of bringing the suit (attorneys' fees, court costs, and so forth). ${ }^{27}$ By conducting the analysis for both arbitration

${ }^{25}$ For purposes of this Article, arbitration means a method of dispute resolution in which the parties present their case to an arbitrator or arbitrators, who then issue a binding decision on the case. Interestingly, there is no definition of arbitration in the Federal Arbitration Act. 9 U.S.C. $\S \S 1-16(2000)$.

${ }_{26}$ This analysis is based on a version of expected utility theory common to law and economics analysis. The crux of the theory is that rational economic actors will choose between various options by selecting the option with the highest expected utility. Decisionmakers must determine the various utilities that each option represents, modified by the probability that the utility will occur. For a discussion of expected utility theory in legal analysis, see Russell B. Korobkin \& Thomas S. Ulen, Law and Behavioral Science: Removing the Rationality Assumption from Law and Economics, 88 CAL. L. REV. 1051, 1062-64 (2000).

${ }^{27}$ This litigation model is based on models developed and used in seminal law and economics analyses. See, e.g., PosNER, supra note 17, at 567-71 (discussing formula for 
and litigation, an employee could determine which alternative offered the most utility by determining which alternative provided the higher value. Thus, the decision to choose arbitration over litigation could be expressed as:

$$
P_{a} * R_{a}-C_{a}>P_{l} * R_{l}-C_{l}
$$

Such a calculation might proceed as follows: Employee Amy has a claim against her employer. She knows that if she litigates the claim, she would have a $70 \%$ chance of winning an average award of $\$ 10,000$. But she knows that her costs, including attorney's fees, would be $\$ 3,000 .{ }^{28}$ If she chooses arbitration, she knows she would only have a $60 \%$ chance of winning $\$ 8,000$. Her costs, however, would only be $\$ 500$. Since the net expected utility of litigation would be $(0.7 * \$ 10,000)-\$ 3,000$, or $\$ 4,000$, and the net expected utility of arbitration would be $(0.6 * \$ 8,000)-\$ 500$, or $\$ 4,300$, Amy would choose arbitration.

The party defending the lawsuit would also use a cost-benefit analysis to determine whether it desired to go to arbitration or litigation. When defending a suit, the expected relief has a negative value rather than a positive value. Thus, defendants try to minimize their losses rather than maximize their gains. In choosing between arbitration and litigation, Amy's employer, AA Co., would conduct an analysis similar to Amy's, except that AA Co. would try to minimize the expected relief rather than maximize it, and AA Co.'s costs for both litigation and arbitration would be different. Thus, if AA Co. has costs of $\$ 1,000$ for litigation and $\$ 500$ for arbitration, the net expected value of litigation would be calculated as $(0.7 *-\$ 10,000)-$ $\$ 1,000$, or $-\$ 8,000$, and the net expected value of arbitration would

condition for litigation to occur); Hylton, supra note 17, at 218-29 (presenting models of litigation and arbitration in context of social value); Samuel Issacharoff, The Content of Our Casebooks: Why Do Cases Get Litigated?, 29 FLA. ST. U. L. REv. 1265, 1268-70 (2002) (discussing models of expected value and probable outcome of litigation); George L. Priest \& Benjamin Klein, The Selection of Disputes for Litigation, 13 J. LEGAL STUD. 1, 9-12 (1984) (discussing formulations of parties' expectations); Shavell, supra note 17, at 23 (presenting standard model of litigation). The cost variable $C$ also includes various nondirect costs, such as the cost of publicity if the suit is litigated. In the examples provided, I assume such costs are zero.

28 This model assumes a noncontingency fee arrangement. If the attorney were working on contingency, the equation would be $P^{*}(R-C)$, rather than $P^{*} R-C$. 
be $(0.6 *-\$ 8,000)-\$ 500$, or $-\$ 5,300 .^{29}$ AA Co. would also choose arbitration.

Obviously, this cost-benefit analysis is a simplified version of a much more complicated assessment of litigation and arbitration outcomes. ${ }^{30}$ But the factors discussed above are the basic factors by which the parties would make their assessments about choice of forum. Moreover, if we can make certain assumptions about those factors, we can make certain predictions about how the parties will behave. For example, if we assume that: (1) litigation will always have a higher expected relief $(P * R)$ than arbitration for the employee, and (2) costs for arbitration will always be lower for both sides than will costs for litigation, then a rational employer will always choose arbitration over litigation. ${ }^{31}$ Moreover, if we make the same assumptions, an employee will choose arbitration if the difference in costs between arbitration and litigation is greater than the difference in expected relief between litigation and arbitration. In the example above, the difference in costs for the employee was $\$ 3,000-\$ 500$, or $\$ 2,500$, which is greater than the difference between $(0.7 * \$ 10,000)$ and $(0.6 * \$ 8,000)$, or $\$ 2,200 .^{32}$

Although the two assumptions about expected relief and costs of litigation and arbitration discussed above may represent the conventional wisdom on the subject, we cannot say empirically that they are true. Proponents of arbitration would argue with the assumption that the employee always has a higher expected relief in litigation than arbitration. ${ }^{33}$ Such proponents would argue arbitrators should be no more biased against employees than juries,

${ }^{29}$ For purposes of this model, I assume both parties have perfect information about the plaintiff's likelihood of success and the potential for relief. Many litigation models assume that the parties will have different expectations about their likelihood of success. The possibility for such divergence is discussed later in this section.

${ }^{30}$ For example, the probability of success and expected-relief factors could encompass a variety of possibilities: a $40 \%$ chance of getting nothing, a $20 \%$ chance of getting $\$ 10,000$, a $20 \%$ chance of getting $\$ 30,000$, a $15 \%$ chance of getting $\$ 60,000$, a $4 \%$ chance of getting $\$ 200,000$, and a $1 \%$ chance of getting $\$ 1,000,000$.

${ }_{31}$ Expressed using variables, since $\left(P_{a} * R_{a}\right)<\left(P_{l} * R_{\nu}\right)$, and $C_{a}<C_{l}$, and since an employer seeks to reduce its costs, it will always choose arbitration.

32 Expressed as a calculation, the employee will choose arbitration if: $\left(C_{l}-C_{\alpha}\right)>\left(P_{l} * R_{\nu}\right)-\left(P_{a} * R_{\alpha}\right)$.

33 E.g., Samuel Estreicher, Saturns for Rickshaws: The Stakes in the Debate over Predispute Employment Arbitration Agreements, 16 OHIO ST. J. ONDISP. RESOL. 559, 564 (2001) (arguing that claimants may win more cases in arbitration than in court). 
and an arbitral award might have a higher expected value since it would be granted more quickly than a litigation award. ${ }^{34}$ However, opponents of arbitration would argue that litigation costs will not necessarily be higher than arbitration costs, especially given the need to pay for the arbitrators themselves. ${ }^{35}$ This Article makes no effort to ascertain whether arbitration is generally more or less fair or more or less expensive. My point here is that economically rational employers and employees would calculate the costs and benefits of an arbitration agreement before deciding to sign and would only execute the agreement if the benefits outweigh the costs.

In the hypothetical above, the decision to choose arbitration over litigation is efficient for both Amy and AA Co., leading them both to choose it independently. What if arbitration was a better deal for the employer, but the employee expected a better result from litigation? If they have perfect knowledge, we still expect the parties to choose the forum that provides the greatest utility for both parties as a whole. The Coase Theorem teaches us that the initial assignment of rights - in this example, the right of the employee to choose litigation-should not stand in the way of arbitration if arbitration is the more efficient result. ${ }^{36}$ If the parties have perfect

\footnotetext{
${ }^{34}$ A recent study of employment arbitration and litigation among higher-paid employees found no statistically significant differences between employee win rates or award levels in arbitration and litigation. Theodore Eisenberg \& Elizabeth T. Hill, Employment Arbitration and Litigation: An Empirical Comparison 8 (2003) (Public Law \& Legal Theory Research Paper No. 65, NYU School of Law), available at http://papers.ssrn.com/sol3/papers.cfm? abstract $\$ i d=389780$ [hereinafter Eisenberg \& Hill, Employment Arbitration and Litigation]. For a condensed version of this article, see Theodore Eisenberg \& Elizabeth Hill, Arbitration and Litigation of Employment Claims: An Empirical Comparison, 58 DisP. RES. J. 44 (Nov. 2003/Jan. 2004).

35 A report by Public Citizen found no evidence that arbitration reduces the overall transaction costs of litigation. Public Citizen, The Costs of Arbitration (May 10, 2002), at http://www.citizen.org/publications/release.cfm?ID=7173.

36 See Herbert Hovenkamp, Marginal Utility and the Coase Theorem, 75 CoRneLL L. REv. 783, 783 (1990) (discussing Ronald H. Coase, The Problem of Social Cost, 3 J.L. \& Econ. 1 (1960)). The Coase Theorem has been the subject of intense academic discussion and debate as to its meaning and validity. See, e.g., Daniel A. Farber, Parody Lost/Pragmatism Regained: The Ironic History of the Coase Theorem, 83 VA. L. REV. 397, 398 (1997) (arguing that Coase never believed his Theorem applied to real world); Stephen G. Medema, Through a Glass Darkly or Just Wearing Dark Glasses? Posin, Coase, and the Coase Theorem, 62 TEnN. L. REV. 1041, 1041 n.4 (1995) (citing attempts to "prove, disprove, confirm, or refute the Coase Theorem"); Daniel Q. Posin, The Coase Theorem: Through a Glass Darkly, 61 Tenn. L. Rev. 797, 799 (1994) (arguing Coase Theorem is "in error"). Although I do not wish to wade into this debate, the Coase Theorem seems logical within its fairly constrained paradigm.
} 
information and can freely bargain, then the employer would bargain with the employee to choose arbitration. Although arbitration alone would make the employee worse off than litigation, the employer would offer to compensate the employee sufficiently so that the employee would find it more advantageous to choose arbitration. Ultimately, the parties would agree to whichever outcome would be more efficient overall. ${ }^{37}$

In order to model this process, we need to compare the employee's cost-benefit analysis with the employer's cost-benefit analysis. When calculating combined utility for the two parties, we would compare the joint utilities of arbitration with the joint utilities of litigation. Thus, the parties would choose arbitration if the expected value of arbitration is greater than the expected value of litigation, or:

$\left(P_{a} * R_{\alpha}\right)-C_{a(e e)}+\left(P_{a} *-R_{\alpha}\right)-C_{a(e r)}>\left(P_{l} * R_{\nu}\right)-C_{l(e e)}+\left(P_{l} *-R_{\nu}\right)-C_{l(e r)}$.

Interestingly, the expected relief $(P * R)$ drops out of the equation since the value of the expected relief is the same for both parties, but expected relief is a benefit for the employee $(P * R)$ and a cost for the employer $\left(P^{*}-R\right)$. Thus, the calculation could simply be expressed as arbitration will be chosen if:

$$
-C_{a(e e)}-C_{a(e r)}>-C_{l(e e)}-C_{l(e r) \cdot}^{38}
$$

In other words, the parties would choose arbitration if the joint costs of taking the claim to arbitration are less than the joint costs of taking the claim to litigation.

This determination is significant because if the costs for both parties are always less in one forum-say, arbitration-than the other, then arbitration will always be the most efficient outcome. And therefore, the employer and employee will always choose arbitration if they have perfect knowledge and can bargain, no matter how much more favorable arbitration is to one party. As an

\footnotetext{
${ }^{37}$ Cf. Hylton, supra note 17, at 212 n.5 ("[A]mong informed parties the incentive to waive the right to litigate is observed when and only when litigation reduces society's wealth.").

${ }^{38}$ This equation could also be represented as arbitration will be chosen if:

$$
\left(C_{a(e))}+C_{a(e r)}\right)<\left(C_{l(e e)}+C_{l(e r)}\right) \text {. }
$$
}


example, imagine a situation in which the arbitration is heavily stacked in favor of the employer. Employee Bob has a claim that has a $90 \%$ chance of earning him $\$ 100,000$ in litigation but only a $10 \%$ chance of earning him $\$ 20,000$ in arbitration. His costs in litigation would be $\$ 400$, and his costs in arbitration would be $\$ 500 .{ }^{39}$ Bob would readily choose litigation after making the following costbenefit analysis:

$$
\begin{gathered}
P_{a} * R_{a}-C_{a}<P_{l} * R_{l}-C_{l} \\
(0.1 * \$ 20,000)-\$ 500=\$ 1,500<(0.9 * \$ 100,000)-\$ 400=\$ 89,600 .
\end{gathered}
$$

In comparing the possible outcomes of arbitration and litigation, the employer, BB Inc., faces the same probability of loss as Bob faces for gain: a $90 \%$ chance of losing $\$ 100,000$ in litigation, but only a $10 \%$ chance of losing $\$ 20,000$ in arbitration. Assume, however, that BB Inc. has costs of $\$ 2,000$ in litigation and $\$ 500$ in arbitration. Thus, BB Inc. would want to pursue arbitration based on the following analysis:

$$
\begin{aligned}
(0.1 *-\$ 20,000)-\$ 500= & -\$ 2,500>(0.9 *-\$ 100,000)-\$ 2,000= \\
& -\$ 92,000 .
\end{aligned}
$$

As discussed above, joint utility is calculated solely based on the costs of both methods since the expected returns for both sides cancel each other out. ${ }^{40}$ The following equation illustrates that arbitration has a higher joint utility than litigation:

$$
\begin{gathered}
-C_{a(e e)}(\$ 500)-C_{a(e r)}(\$ 500)=-\$ 1,000>-C_{l(e e)}(\$ 400)-C_{l(e r)} \\
(\$ 2,000)=-\$ 2,400 .
\end{gathered}
$$

Arbitration will save the parties $\$ 1,400$ in joint efficiency.

\footnotetext{
39 I set litigation costs as lower than arbitration costs to weight Bob's preference for litigation even more heavily.

40 The $\$ 90,000$ expected return to the employee through litigation is an expected $\$ 90,000$ loss to the employer, and the $\$ 2,000$ expected return to the employee through arbitration is an expected $\$ 2,000$ loss to the employer.
} 
How would the employer convince the employee to take the case to arbitration? BB Inc. would have to pay Bob the difference in utility. Since litigation has a greater utility of $\$ 88,100$ for Bob, but arbitration has a greater utility of $\$ 89,500$ for BB Inc. ${ }^{41}$ both parties would be better off if BB Inc. paid Bob between $\$ 88,100.01$ and $\$ 89,499.99$ to take the case to arbitration. If the employer paid, say, $\$ 89,000$ to the employee, Bob's calculation would be:

$$
\begin{gathered}
(0.1 * \$ 20,000)-\$ 500+\$ 89,000=\$ 90,500(A R B)>(0.9 * \\
\$ 100,000)-\$ 400=\$ 89,600(L I T)
\end{gathered}
$$

while BB Inc.'s calculation would be:

$$
\begin{gathered}
(0.1 *-\$ 20,000)-\$ 500-\$ 89,000=-\$ 91,500(A R B)>(0.9 *-\$ 100,000) \\
-\$ 2,000=-\$ 92,000(\text { LIT }) .
\end{gathered}
$$

Thus, both parties would agree to arbitrate. They would split the efficiency surplus: Bob would receive $\$ 900$ of the surplus, and BB Inc. would receive $\$ 500$ of the surplus.

Thus, if the parties have perfect information and can freely bargain, they will always choose the method of dispute resolution with the lowest total cost for both sides. In this example, arbitration represented a double hit for employee Bob. Not only was Bob's expected reward much greater in litigation than in arbitration, but his costs were higher in arbitration as well. However, since BB Inc.'s costs were significantly higher in litigation than in arbitration, it was more efficient for the parties to choose arbitration. In order to persuade Bob to choose this route, BB Inc. needs to pay Bob a portion of the surplus generated by arbitration. Even after paying this large sum, BB Inc. will still be better off than if it had litigated. ${ }^{42}$

\footnotetext{
41 For Bob, the arbitration result $(\$ 1,500)$ is $\$ 88,100$ less than the litigation result $(\$ 89,600)$, while for BB Inc. the arbitration result $(-\$ 2,500)$ is $\$ 89,500$ more than the litigation result $(-\$ 92,000)$.

${ }_{42}$ Note that this payment is only necessary because the employee has a right to take the case to litigation and therefore has a veto over arbitration. The parties would choose arbitration without any exchange of funds if arbitration was the societal default.
} 
Of course, if the parties had perfect information about the expected value of the claim, they would be able to settle the claim and avoid incurring dispute resolution costs entirely. ${ }^{43}$ The decision to litigate depends on uncertainty-uncertainty about the chance of victory, the potential award, and the costs of litigating. Parties may not settle if they do not agree upon the basic components of the decision to settle: the probability the plaintiff will win, the expected value of the plaintiff's relief, and the costs incurred by both sides in litigating. ${ }^{44}$ Since all of these components are predictions, parties will have different sets of predictions. The same holds true for the decision to choose arbitration instead of litigation. Once parties have failed to settle their claim, they may then make a decision about whether to take the claim to arbitration. If the parties both have perfect information about these various factors and can then bargain over which outcome to choose, they will reach the most efficient result. But if the parties base their decision on different sets of information, they may not come to the efficient conclusion. The parties may either fail to agree on the most efficient outcome, or they may both agree to the less efficient outcome. ${ }^{45}$ Again, an example may best illustrate this.

As discussed, both employee and employer would choose arbitration under the following scenario: In litigation, employee Amy has a $70 \%$ chance of winning an average award of $\$ 10,000$, with costs of $\$ 3,000$. In arbitration, Amy would have a $60 \%$ chance of winning $\$ 8,000$, with costs of $\$ 500$. Since the net expected utility of arbitration would be $(0.7 * \$ 10,000)-\$ 3,000$, or $\$ 4,000$, and the net

43 See PosNeR, supra note 17, at 567 ("That cases are ever litigated rather than settled might appear to violate the principle that when transaction costs are low, parties will voluntarily transact if a mutually beneficial transaction is possible."); Russell Korobkin \& Chris Guthrie, Psychological Barriers to Litigation Settlement: An Experimental Approach, 93 Mich. L. REV. 107, 112 (1994) ("As long as the costs of trial are higher than the costs of settlement, and as long as both sides make an identical estimate of the likely outcome of the trial, the case should settle.").

${ }^{44}$ See PosNER, supra note 17, at 568 ("Settlement might appear especially unlikely if the parties, by virtue of having different information about the strength of their respective cases, do not agree on the likely outcome of the litigation.").

${ }_{45}$ Settling the case will always be the more efficient choice, since settlement costs will always be less than litigation costs. In choosing between arbitration and litigation, however, the parties may determine that litigation actually costs less than arbitration. Thus, a failure to reach an agreement to arbitrate will not always lead to an inefficient result, whereas the failure to reach an agreement to settle will always lead to an inefficient result. 
expected value of arbitration would be $(0.6 * \$ 8,000)-\$ 500$, or $\$ 4,300$, Amy should choose arbitration. Suppose, however, that Amy has information that leads her to calculate the expected benefits of litigation and arbitration incorrectly. For example, Amy may believe that she has a $90 \%$ chance of winning $\$ 20,000$ in litigation, but only a $40 \%$ chance of winning $\$ 5,000$ in arbitration. Even with perfect information about costs, Amy would make the incorrect decision to litigate the case since her (incorrect) expected benefit of litigation $(0.9 * \$ 20,000-\$ 3,000=\$ 15,000)$ would be much higher than her (incorrect) expected benefit of arbitration $(0.4 * \$ 5,000-\$ 500=$ $\$ 1,500)$. AA Co. would be unwilling to pay Amy the $\$ 13,500$ necessary to convince her to arbitrate, ${ }^{46}$ and therefore, Amy would inefficiently take the case to court.

As in all cost-benefit analyses, information is crucial to determining whether to arbitrate or litigate. Thus, the relative efficiency of parties' decisions to litigate or arbitrate will depend on how closely their information about those two processes resembles reality and how well their information predicts the results of those two processes. If parties consistently make poor predictions based on incorrect assumptions about the differences between arbitration and litigation, then parties may consistently make inefficient decisions. As illustrated in the hypothetical above, if employees consistently overestimate their potential for litigation success and underestimate their potential for arbitral success, they may inefficiently choose litigation over arbitration.

Based on our cost-benefit model, we can draw several conclusions about potential agreements to arbitrate employment claims after those claims have arisen. First, the forum with the lower costs will be the more efficient choice. Second, if the parties have perfect information about the probability of success, the expected relief, and the costs in each forum with respect to the claim at issue, the parties will bargain to reach the most efficient outcome. Third, if parties do

\footnotetext{
46 In the case discussed above involving Amy, we said that AA Co. had costs of $\$ 1,000$ for litigation and $\$ 500$ for arbitration, and thus, the net expected value of litigation for the employer would be $(0.7 *-\$ 10,000)-\$ 1,000$, or $-\$ 8,000$, and the net expected value of arbitration would be $(0.6 *-\$ 8,000)-\$ 500$, or $-\$ 5,300$. Thus, the employer would only be willing to pay Amy up to $\$ 2,700$ to arbitrate rather than litigate.
} 
not have perfect information, they may end up in the less efficient forum.

B. THE COST-BENEFIT ANALYSIS BEHIND THE PREDISPUTE ARBITRATION AGREEMENT

Thus far we have modeled the decision to arbitrate or litigate after the employee's dispute arose. Predispute employment arbitration agreements, however, are signed at the beginning of employment, well before any disputes arise. Although the types of claims covered by a particular agreement are left up to the parties, a standard scope of coverage is all claims arising from the course of employment, including common-law claims as well as state and federal statutory claims. ${ }^{47}$ In order to determine whether it is more efficient to assign all of these claims to arbitration, both employers and employees will want to know the same type of information as in the postdispute context: their probability of success in arbitration and litigation, their expected gains (or losses) from both forums, and their costs in both forums. There is, of course, one major difference. In the postdispute context, the parties know exactly what the dispute is about and, therefore, what the legal claim will be. In the predispute context, however, the parties will have to predict the types and the likelihood of the different claims that could arise during the employment relationship. Moreover, employees are often asked to sign a predispute arbitration agreement as a condition of employment. As a result, employees must weigh the costs and benefits of the agreement against the costs and benefits of taking this job over a different job, which may or may not require a predispute arbitration agreement. The employee does not decide the merits of arbitration versus litigation as a stand-alone proposition. The employee must weigh this comparison against the costs and benefits of the job offered as opposed to other potential jobs. The calculations are much more complicated.

As in the postdispute context, an employee will base the decision to sign a predispute agreement on the probability of success, the

\footnotetext{
${ }^{47}$ This model assumes that the "claims" at issue are those brought by an employee against an employer.
} 
expected relief, and the costs of arbitration as compared with the probability of success, the expected relief, and the costs of litigation. This model in the postdispute context is expressed as:

$$
P_{a} * R_{a}-C_{a} \text { compared with } P_{l} * R_{l}-C_{l} \text {. }
$$

Rather than considering this with respect to one dispute with ascertained facts and a cause (or causes) of action, the employee must make the decision as to the potential causes of action that may arise during her employment. To be even more precise, the employee must predict the myriad possibilities for different factual scenarios involving employment law claims. After all, potential employment claims can vary widely in their expected likelihood of success, amount of relief, and costs of litigation. ${ }^{48}$

How do we go about modeling this? In the postdispute context, the calculation was limited to determinations about the probability of success, expected relief, and probable costs of the action that had already arisen. For example, in a potential Title VII case, the employee would ask: Given what happened, what are my chances of success? Is my case based on statistical data, or is there a smoking gun proving direct discrimination? The expected relief could also be calculated by asking: Did the employee lose wages? Did the employee suffer personal pain, humiliation, and suffering? Are punitive damages a possibility? Employees and their attorneys can work through the Kolstad factors ${ }^{49}$ to determine whether they have a valid claim for punitive damages and whether the arbitration forum will accept punitive damages claims. Costs, primarily attorney's fees, are also possible to calculate by asking: What is the complexity of the case? What is the evidence that each side has? How long would a trial last? Predictions about these matters can be based on the actual case combined with relatively accessible information about past cases. The fact that most parties settle

${ }^{48}$ This is true even if you limit the potential claims to a particular cause of action. For example, the expected relief would be much lower in a statistically based failure-to-promote Title VII case than in a Title VII case involving termination for failure to accede to a sexual quid pro quo.

${ }^{49}$ In Kolstad v. American Dental Association, the Supreme Court set forth factors to consider when making a punitive damages determination under Title VII of the Civil Rights Act of 1964. 527 U.S. 526, 546 (1999). 
supports the inference that parties can make rational calculations on these matters. ${ }^{50}$

Consider, now, these calculations from the perspective of a prospective employee. Overall, the employee will be attempting to determine the difference in value between taking claims to arbitration and taking claims to litigation. But how would an employee go about figuring this out? One possibility would be to rely on statistics about the overall difference between arbitration outcomes and litigation outcomes. Obviously, though, aggregate statistics are not the answer. For starters, such statistics are not readily available. ${ }^{51}$ But even if they were, they would only be a crude approximation. Settlements are not included in the statistics. Employees who do not sign predispute agreements may be in a position to achieve more lucrative settlements than employees who sign arbitration agreements. And since such settlements are generally confidential, it is impossible to get a sense of the difference. In addition, national averages are at best a rough approximation of the costs and benefits to this particular employee working in this particular region at this particular firm in this particular department. Since parties have the freedom to craft their own rules and procedures for the arbitral forum, the employee would have to assess the system of rules and procedures offered by this employer against the rules and procedures generally used in other arbitrations. Even if arbitration results are roughly comparable to litigation results at the national level, this employer's arbitration system may have results that differ widely from the national average.

However, the most crucial difference in the predispute context is that the employee must factor in a new variable: the likelihood that

50 See Marc Galanter \& Mia Cahill, "Most Cases Settle": Judicial Promotion and Regulation of Settlements, 46 STAN. L. REV. 1339, 1339-40 (1994) (stating most estimates find that between $85 \%$ and $90 \%$ of cases resolve before trial). Galanter and Cahill observe, however, that many of these cases are resolved through judicial decisions on important or dispositive motions or even through arbitration. Id. at 1340. They argue that two-thirds is a better estimate of the number of cases that settle voluntarily (i.e., without a definitive judicial ruling). Id.

51 At best, analyses of limited pools of arbitration results may be found in academic or practitioner publications. See, e.g., Eisenberg \& Hill, Employment Arbitration and Litigation, supra note 34 , at 8 (finding "no statistically significant differences between arbitration and litigation in employee win rates"). 
any particular fact scenario involving a potential employment law violation will arise during the course of employment. In other words, the employee will have to determine the likelihood that the employer will violate any employment law covered under the agreement. ${ }^{52}$ Thus, to be completely thorough, an employee would have to (1) contemplate each of myriad different scenarios under which the employee would be entitled to legal relief, (2) determine the likelihood of each individual scenario, and (3) determine how each scenario would fare in terms of probability of success, expected relief, and costs in both litigation and arbitration.

Thus, the cost-benefit analysis for each agreement would have to take all of these factors into account in comparing arbitration with litigation. This calculation might be expressed as follows:

$$
\begin{gathered}
{\left[X(1) *\left(P(1)_{a} * R(1)_{a}-C(1)_{a}\right)\right]+\ldots+\left[X ( n ) * \left(P(n)_{a} * R(n)_{a}-\right.\right.} \\
\left.\left.C(n)_{a}\right)\right] \\
\text { as compared with } \\
{\left[X(1) *\left(P(1)_{l} * R(1)_{l}-C(1)_{\nu}\right)\right]+\ldots+\left[X ( n ) * \left(P(n)_{l} * R(n)_{l}-\right.\right.} \\
\left.\left.C(n)_{\nu}\right)\right] .{ }^{53}
\end{gathered}
$$

In this model, $X$ is the probability of any particular factual scenario arising, and $n$ represents the total number of different scenarios an employee could encounter during the course of employment. The other variables would remain the same but would need to be calculated for each scenario. The variable $P(1)_{a}$, for example, would represent the probability of success at arbitration for claims relating to the first potential scenario. Through this model, the employee is calculating the probability of success, the expected relief, and the costs for each possible fact scenario and then discounting the result

\footnotetext{
${ }^{52}$ Although it would be possible to limit an arbitration agreement to cases concerning violations of only certain laws, employment arbitration agreements generally include all claims arising out of the course of employment. See, e.g., JAMS Guide to Dispute Resolution for Employment Programs and Sample Clause Language, available at http://www.jamsadr. com/rules/employment\$clauses.asp (last visited Oct. 1, 2004) (showing sample arbitration clause).

53 This comparison could also be expressed as: $3_{n}^{1} X *\left(P_{a} * R_{a}-C_{a}\right)$ as compared with $3_{n}^{1} X *\left(P_{1} * R_{1}-C_{1}\right)$.
} 
by the probability that the scenario will occur. The totals for all such possible scenarios are then added together for arbitration and for litigation, and the employee would choose whichever is higher.

An absurdly simplified example of such a calculation would be as follows: Employee Claire is going to work for an employer who wants her to sign a predispute agreement to arbitrate. She knows that there is a $10 \%$ chance that she will be improperly denied overtime compensation and a 5\% chance that her supervisor will blatantly discriminate against her because of her sex. Under the overtime compensation scenario, Claire has a 50\% chance of winning $\$ 10,000$ from a jury, with costs of $\$ 1,000$, while she has a $40 \%$ chance of winning $\$ 8,000$ from an arbitrator, with costs of $\$ 500$. Under the supervisor discrimination scenario, she has an $80 \%$ chance of winning $\$ 100,000$ from a jury (including punitive damages), with costs of $\$ 4,000$, while she has an $80 \%$ chance of winning $\$ 50,000$ from an arbitrator, with costs of $\$ 1,000$. Her calculation would be as follows:

$$
\begin{gathered}
(0.1 *((0.5 * \$ 10,000)-\$ 1,000))+(0.05 *((0.8 * \$ 100,000)-\$ 4,000)) \\
=\$ 400+\$ 3,800=\$ 4,200 \text { under litigation } \\
\text { and } \\
(0.1 *((0.4 * \$ 8,000)-\$ 500))+(0.05 *((0.8 * \$ 50,000)-\$ 1,000))= \\
\$ 350+\$ 1,950=\$ 2,300 \text { under arbitration. }
\end{gathered}
$$

Thus, since the expected value of litigating the potential claims would be $\$ 4,200$, while the expected value of arbitrating the expected claims would be $\$ 2,300$, Claire would choose not to sign the arbitration agreement, all else being equal. Alternatively, Claire would require a payment of at least $\$ 1,900.01$ in exchange for signing the arbitration agreement. ${ }^{54}$

If employees had perfect knowledge, they could determine the efficiency of signing a predispute arbitration agreement, and they

\footnotetext{
${ }^{54}$ If the employer paid Claire $\$ 1,900.01$ to sign the arbitration agreement, her expected value for the agreement would be $\$ 2,300+\$ 1,900.01$, or $\$ 4,200.01$. The expected value of litigation for Claire is $\$ 4,200$.
} 
could bargain with the employer to arrive at the most efficient outcome. But the likelihood that employees would have anything approaching the necessary "perfect information" to make such a decision is surely close to zero. ${ }^{55}$ In comparison to the information available to employees in the postdispute context, predispute information borders on fantasy. After a dispute has arisen, the facts of the dispute are largely known to employer and employee, and both sides can make predictions about the likelihood of success, potential damages, and potential costs. But at the beginning of an employment relationship, the employee would have to know the likelihood of success, potential damages, and potential costs for actions that have not yet happened. In addition, an employee would have to know the likelihood that those actions would take place. While a new employee may have a hazy sense of the potential for legal claims arising out of the workplace and may even have a sense of whether this particular employer has a past history of illegal activity, she would need clairvoyance to determine the likelihood that her employer would violate her employment rights. Even if the employer kept meticulous track of previous violations and provided data to new employees on arrival, that data would offer no guarantee that past trends would continue into the future. The hiring of a new supervisor, an unexpected merger, and even the employee's personal choices about marriage, pregnancy, or dating could affect the likelihood that the employer will violate the employee's rights. Moreover, new causes of action could arise, or courts could take a stricter interpretation of existing statutes.

There is also a potential moral hazard problem. "Moral hazard" refers to the tendency of an insured person to relax his or her precautionary measures because he or she no longer has to worry

55 See Eileen Silverstein, From Statute to Contract: The Law of the Employment Relationship Reconsidered, 18 HofsTRA LAB. \& EMP. L.J. 479, 525 (2001). A fundamental problem with enforcing [predispute waivers and arbitration agreements] is the inability of employees and applicants to assess the choices offered, because there is no contemporaneous and concrete employment dispute at the time the employees or applicants agree to forego litigation over past and present claims or to submit future claims to Id. arbitration. 
about an unfavorable outcome. ${ }^{56}$ In the postdispute context, an agreement to arbitrate will not affect an employer's decision to engage in prohibited conduct since the agreement applies only to an event that has already occurred. In the predispute context, however, a binding agreement not to litigate may affect whether an employer engages in prohibited behavior or whether an employer takes precautionary measures against such behavior. ${ }^{57}$ If the arbitration agreement changes the expected costs and benefits of engaging in arguably prohibited behavior, the employer will have different incentives with regard to that behavior.

This point is most simply shown by considering a predispute agreement to waive all claims. If an employee were to sign an agreement waiving all potential statutory claims against the employer, then the employer would have no incentive to prevent such claims from arising. The employer would have no incentive to take precautionary efforts to prevent employees and managers from engaging in activities that violate the employee's rights. ${ }^{58}$ The expected costs of litigation would normally provide a significant "cost" to the illegal behavior and thereby justify taking precautionary measures. However, the elimination of potential litigation by the waiver agreement removes those costs.

As Keith Hylton has pointed out, a predispute arbitration agreement has much in common with a waiver agreement. ${ }^{59}$ "An arbitration agreement, after all, is simply a form of waiver, in which the plaintiff waives the right to sue in court rather than the right to sue altogether." ${ }^{60}$ If the arbitration agreement provides the parties with a forum more favorable to the employer, the employer's cost of engaging in prohibited activity will be reduced. That reduction may in turn lead the employer to curtail its precautionary efforts. The

56 PosNer, supra note 17, at 109.

57 See Hylton, supra note 17, at 218 (arguing that deterring socially harmful conduct is key social benefit from litigation).

58 Indeed, to the extent that the "employer" is a person-say, a sole proprietor-the employer could engage in such activity if he or she derived utility from such behavior. Although some individuals may derive utility from discrimination itself, this utility is generally ignored for purposes of determining societal utility. See generally GARY S. BECKER, THE ECONOMICS OF DiscRIMINATION (2d ed. 1971) (discussing economic considerations of discrimination).

59 Hylton, supra note 17, at 223.

60 Id. 
employer's decision will be based on a comparison between the costs of the precaution and the costs of the arbitral forum. Of course, the employer will not know exactly what damage the prohibited activity will cause or the exact difference in bias between arbitration and litigation. But if an employer sets up a completely one-sided arbitration regime, the employer will be able to discount the costs of the prohibited activity significantly. This may lead to a greater probability that the employer will fail to take precautions against such activity. ${ }^{61}$

In deciding whether to sign a predispute arbitration agreement, the employee would have to take this "moral hazard" problem into account. The probability that a particular scenario raising employment law issues would occur (represented by $X$ in our equation) would not be the same for arbitration and litigation. If one forum is more favorable to the employer than the other, then the extent of the favorability will affect the employer's probability of engaging in the activity. Thus, we must have separate probabilities for arbitration. The new analysis would be expressed:

$$
\begin{gathered}
{\left[X_{a}(1) *\left(P(1)_{a} * R(1)_{a}-C(1)_{a}\right)\right]+\ldots+\left[X _ { a } ( n ) * \left(P(n)_{a} * R(n)_{a}-\right.\right.} \\
\left.\left.C(n)_{a}\right)\right],
\end{gathered}
$$

as compared with

$$
\left[X_{l}(1) *\left(P(1)_{l} * R(1)_{l}-C(1)_{\nu}\right)\right]+\ldots+\left[X _ { l } ( n ) * \left(P(n)_{l} * R(n)_{l}-\right.\right.
$$

\footnotetext{
${ }^{61}$ An example of such a situation is described by Keith N. Hylton in his article Agreements to Waive or to Arbitrate Legal Claims: An Economic Analysis. Hylton, supra note 17, at 219, 224. Hylton supposes that an employer's agents could potentially be involved in an activity that would cause $\$ 100$ in damage to the employee. Id. If the employer takes care, the chance of such an injury is $25 \%$; if no care is taken, the chance of injury is $75 \%$. Id. The cost of care is $\$ 25$. Id. Hylton then assumes that litigation would always correctly award the employee $\$ 100$ if the injury took place. Id. Under such a regime, the employer would take care because the cost of taking care, $\$ 25+(1 / 4 * \$ 100)=\$ 50$, would be less than the cost of not taking care, $3 / 4 * \$ 100=\$ 75$. However, suppose the employer and the employee had signed a predispute arbitration agreement. If the arbitral forum were biased against the employee such that the employer was only held liable $25 \%$ of the time, the employer would not take care, $.75(.25 *$ $\$ 100)=\$ 18.75$, rather than take care, $\$ 25+(1 / 4 *(.25 * \$ 100))=\$ 31.25$. Hylton's example also included the costs of arbitration, which I have left out for simplicity.

${ }^{62}$ Or:
}

$$
3_{n}^{1} X_{a} *\left(P_{a} * R_{a}-C_{a}\right) \text { as compared with } 3_{n}^{1} X_{1} *\left(P_{1} * R_{1}-C_{1}\right)
$$


The only difference in this equation is that instead of $X$ representing the probability of the event in both sets of equations, $X_{a}$ represents arbitration and $X_{l}$ represents litigation. This is a small but significant change because of the calculation it represents. Now, instead of just determining the probability that the employer will engage in prohibited activity, the employee must determine that probability as affected by two different adjudicatory forums. The difference will be determined by using the variances between the expected costs of arbitration $\left[\left(P(1)_{a} * R(1)_{a}-C(1)_{a}\right)\right]$, the expected costs of litigation $\left[\left(P(1)_{l} * R(1)_{l}-C(1)_{\nu}\right)\right]$, and the costs of any precautionary measures that could be taken. This will vary for each potential situation. ${ }^{63}$

To add another complicating factor, many (if not most) predispute arbitration agreements are not separately negotiated; they are instead part of the overall employment package offered to the employee. $^{64}$ Thus, the employee cannot look at the agreement separately and decide whether the agreement, standing alone, will increase the employee's utility. Instead, the employee has to weigh the expected value of the arbitration agreement in conjunction with the overall expected utility of taking the particular job. Imagine a prospective employee, having gone through a job search and interview process, who is then presented with a predispute arbitration agreement to sign prior to full-time employment. The employer may treat it like just another of the many forms that the employee must complete. If the employer expresses a willingness to talk about and negotiate the agreement, then the employee has an incentive to perform an independent cost-benefit analysis. But if the employer presents the agreement as a condition of employment, the employee has no choice about the content of the agreement. Instead,

${ }^{63}$ One would expect that as the arbitral forum gets more unfair, the likelihood of prohibited activity increases. At some point, however, the arbitral forum becomes so unfair that there is a likelihood of a successful challenge to the agreement. Thus, the probability function would not be strictly linear.

${ }^{64}$ Exact figures of the percentage of employers who require employees to sign arbitration agreements as a condition of employment are unavailable. However, a number of high-profile cases have involved such agreements. See, e.g., Circuit City Stores, Inc. v. Adams, 279 F.3d 889, 891-92 (9th Cir. 2002) (finding plaintiff employer's mandatory arbitration agreement procedurally and substantively unconscionable); Cole v. Burns Int'l Sec. Servs., 105 F.3d 1465, 1469 (D.C. Cir. 1997) (deciding employer's mandatory arbitration contract enforceable where employee was not required to pay costs of arbitration for statutory claim). 
the employee must weigh the costs and benefits of accepting the job at hand (including the predispute arbitration agreement) against the costs and benefits of going back on the job market. A simplified version of such a decision would be:

$$
\begin{gathered}
J_{j 1}+\left[X_{a}(1) *\left(P(1)_{a} * R(1)_{a}-C(1)_{a}\right)\right]+\ldots+\left[X _ { a } ( n ) * \left(P(n)_{a} * R(n)_{a}-\right.\right. \\
\left.\left.C(n)_{a}\right)\right],
\end{gathered}
$$

as compared with

$$
\left(D_{j 2} *\left(J_{j 2}+{ }^{\prime \prime} 2\right)\right)+\left(D_{j 3} *\left(J_{j 3}+{ }^{\prime \prime} 3\right)\right)+\ldots+\left(D_{j n} *\left(J_{j n}+{ }_{j n}\right)\right) .
$$

In this model, $J_{j 1}$ is the sum of the overall costs and benefits of the job on the table, such as wages, benefits, hours of work required, type of work required, relationship with colleagues, prospects for future promotion, and so on. The only factor not included in $J_{j 1}$ would be the estimated value of the predispute arbitration agreement. Of course, $J_{j 1}$ represents an amalgam of costs and benefits similar to the one constructed for the arbitration agreement. The final expected value of the current job would be compared with the expected values for all other possible jobs.

As for the other variables, jn represents the total number of potential jobs available to the employee. Variable $J$ represents the expected value for each other job that might be available (excluding the arbitration issue), and Drepresents the probability that the employee could get that job. Variable " represents the expected value of an arbitration agreement, if any, that would be required as part of that potential job. In other words, the employee does not know whether other potential jobs will also require her to sign a predispute arbitration agreement. Thus, the employee would have to determine the likelihood that the other job will require an arbitration agreement as well as the expected value of such an agreement (if offered). To break down ", one could construct the following equation:

$$
"=\left(P_{a r b} * V_{a r b}\right)
$$


In the equation, $P_{a r b}$ is the probability that the employer will require an arbitration agreement, and $V_{a r b}$ is the expected value of that agreement (which may be positive or negative).

To be sure, in order to accept a job in the first place, the employee would have to determine that the expected value of the offered job is higher than the expected value of all alternative jobs. Or represented as an equation:

$$
J_{j 1}>\left(P_{j 2} * J_{j 2}\right)+\left(D_{j 3} * J_{j 3}\right)+\ldots+\left(D_{j n} * J_{j n}\right) \cdot{ }^{65}
$$

However, the addition of the arbitration agreement does provide a significant complicating factor. First, as discussed, the expected value of the agreement itself is quite difficult to calculate. Second, even if that can be done, the employee must determine the probability that other employers will also require such agreements and, if they do, whether those agreements will have a similar expected value. After all, other employers may have fewer or greater instances of statutory violations, those violations may be more or less serious, or the arbitration procedures may be more or less fair. Since each employer may differ on these factors, the employee would have to develop separate analyses for each employer in order to be completely accurate.

We have been considering the decision about a predispute arbitration agreement from the perspective of an employee. How would an employer go about deciding whether to propose an arbitration agreement? The basic calculation should be the same: whether the expected value of taking all claims to arbitration would be greater than the expected value of taking the claims to litigation. This calculation would have to account for the probability that such claims would arise. As noted above, the decision might be expressed as:

$\left[X_{a}(1) *\left(P(1)_{a} * R(1)_{a}-C(1)_{\alpha}\right)\right]+\ldots+\left[X_{a}(n) *\left(P(n)_{a} * R(n)_{a}-C(n)_{\alpha}\right)\right]$,

\footnotetext{
65 This equation assumes that the employee has secured only one job. If the employee is choosing between two or more jobs, the employee would compare each job singularly with one of the other jobs, as an employee can only have one full-time job at any given time.
} 
as compared with

$$
\left[X_{l}(1) *\left(P(1)_{l} * R(1)_{l}-C(1)_{\nu}\right)\right]+\ldots+\left[X_{l}(n) *\left(P(n)_{l} * R(n)_{l}-C(n)_{l}\right)\right]
$$

Thus, the employer would also seem to be faced with a difficult decision. The employer, however, has several informational advantages over employees when it comes to making this calculation.

The employer has access to more information about the probability that it will engage in the prohibited behavior $X$. The extent of the employer's knowledge depends, in part, on the extent to which one imparts the knowledge of the employer's agents to the employer itself. For example, a sole proprietor knows all about his or her own past history of, and proclivity for, prohibited activity. A large corporation, on the other hand, may not know what lurks in the hearts of its middle managers. It at least has information about their past activities, however, and can make some predictions about their future behavior. Moreover, a large corporation can take precautionary efforts to prevent or mitigate prohibited behavior: screening applicants for evidence of illegal activity, training new employees about legal rules and ethical conduct, and monitoring and disciplining employees for violations of the rules. ${ }^{66}$ Knowledge of the extent of precautions taken by the employer will lead to a more accurate estimation of $X$.

The employer is also much more likely to have thorough information about the arbitral forum than employees. First, the employer will know the basics about the forum itself: what the arbitration rules are, how the arbitrators are chosen, whether class actions are allowed, whether punitive damages may be awarded, and so on. In fact, the employer may to a large extent craft these rules itself. Certainly, employers can choose an off-the-rack method of arbitration, such as the rules and procedures of the American Arbitration Association. ${ }^{67}$ But employers are choosing the process

66 See Joanna L. Grossman, The Culture of Compliance: The Final Triumph of Form Over Substance in Sexual Harassment Law, 26 HARV. WoMEN's L.J. 3, 40-49 (2003) (discussing effects of employer efforts to reduce harassment).

67 See American Arbitration Association, National Rules for the Resolution of Employment Disputes (Jan. 1, 2004), at http://www.adr.org/index2.1.jsp?JSPssid=15747\&JS 
and thereby will acquire significant information about it. Employees may or may not have access to the procedures when they sign the arbitration agreement and may find it difficult and expensive to obtain a real understanding of those procedures. Certainly, an employer may incur costs in choosing and setting up a method of arbitration, and these costs should be included in the process. But in exchange for these costs, the employer will have a much better sense of the effect of the forum on the probabilities of success, the value of the relief, and the costs of the forum. ${ }^{68}$ Moreover, the employer will gain further information about the process over time, as it experiences actual arbitrations through the agreement. Employees will likely only have exposure to arbitration once. ${ }^{69}$

Finally, if the employer knows that its costs will be lower in arbitration and that its likelihood of success in arbitration will be no less than in litigation, then the employer knows that an arbitration agreement will always make economic sense. Certainly, employees would know the same: They should sign if their costs are lower and their chance of success is no less. But employers should be able to establish these conditions with much more certainty than could employees. As noted, employers can choose the rules and procedures of the arbitral forum. ${ }^{70}$ Thus, employers will know whether those procedures are no more generous to or biased toward the employee than litigation procedures. In fact, the employer can make sure that arbitration procedures do not favor the employee. Employees could theoretically propose alternative rules and procedures to make sure the arbitration procedures do not favor the employer, but the employee is not likely to have enough information to propose a set of alternative rules. In order to develop alternate procedures, an employee would likely need the costly services of an attorney.

Psrc $=$ upload $\backslash$ LIVESITE $\backslash$ Rules $\$$ Procedures $\backslash$ National\$International $\backslash . . \backslash . . \backslash$ focusArea $\backslash$ empl oyment $\backslash 000411$ aa.htm (setting forth rules developed for employers and employees seeking use of private alternatives for dispute resolution).

68 As discussed below in Part III.A.5, the employer can also spread the costs of obtaining this knowledge across all of its employee arbitration agreements, but employees must absorb the costs individually. See infra notes 163-65 and accompanying text.

69 The advantages of the employer's experiences with arbitration over time are often referred to as the "repeat player effect." Lisa B. Bingham, Employment Arbitration: The Repeat Player Effect, 1 EMPLOYEe RTS. \& EMP. PoL'Y J. 189, 190-91 (1997); Cole, supra note 9, at $452-53$.

70 See supra note 67 and accompanying text. 
Moreover, an employer is likely to insist on its own rules, leaving the employee to make the calculation as to whether this job offers more utility than other potential jobs. The end result is that the employer's proposed procedures will likely be the final ones, enabling the employer to ensure at least that the arbitral process does not favor the employee.

C. BEHAVIORAL CONCERNS ABOUT THE PREDISPUTE AGREEMENT ANALYSIS

Given the complexity of these analyses, as well as the lack of information about their underlying factors, it is virtually impossible for employees to make an accurate valuation of the predispute arbitration agreement. In the face of this impossibility, employees might react in different ways. They might assign a high negative value to the arbitration agreement and refuse to sign any such agreement. They might assign an agreement a minimal negative value, or a positive value, and sign the agreement without further thought. Or employees might recognize that the agreement has some value to the employer and negotiate for some benefit in exchange for executing the agreement.

I know of no data, other than anecdotal, that suggests what employees are actually doing. However, there is psychological research that suggests employees are likely to assign minimal positive or negative values to such agreements. The complexity of the decision would probably drive employees to abandon any effort to do a cost-benefit analysis. ${ }^{71}$ While employees may begin to work through the costs and benefits of signing the arbitration agreement, the difficulties in aggregating the factors, as well as the lack of information about each factor, would lead an employee to stop short of a complete analysis. In the face of this frustration, employees may resolve their dilemma through the use of decisionmaking shortcuts, described in the cognitive psychology literature as "heuristics." These heuristics, which have been studied and

${ }^{71}$ Korobkin \& Ulen, supra note 26, at 1078 ("Decision researchers have identified the complexity of a decision as a leading cause of departures from the type of complete cost-benefit analysis of decision options predicted by expected utility theory."). 
developed since the 1970s, have recently received a fair amount of attention in legal academia. Heuristics form the basis for a new approach to legal decisionmaking theory, known as "behavioral decision theory"72 or "behavioral law and economics."73 This approach counsels that the rational actor thesis, found at the core of law and economics, must be tempered based on known "irrationalities" in human behavior. These irrationalities, according to some theorists, stem from an adaptive approach to complex or difficult decisions. ${ }^{74}$ In order to resolve certain types of decisionmaking quandaries, people will often adopt shortcuts, or heuristics, that lead to nonrational decisions in certain types of situations. $^{75}$

The flashpoint we have been examining - the employee's decision to sign a predispute arbitration agreement-may be subject to influence by several of the heuristics identified by researchers. Given the complexities of the predispute agreement analysis, it is not surprising that employees would resort to some form of decisionmaking shortcut in deciding whether to sign. Heuristics that may have an effect on the process are described below.

1. Misconceptions and Probabilistic "Editing." In order to do a complete expected utility calculation regarding potential employment, the employee would have to calculate all of the expected costs and benefits that the proffered job entails. As noted above, the predispute arbitration agreement is only one small factor in the array of terms and conditions of employment. The rational employee would have to proceed step-by-step as to each factor in making the rational utility calculus.

However, there is reason to believe that the employee may not factor in the expected value of a predispute arbitration agreement. To begin with, the employee may not even know that such an agreement is required. Employers are not likely to highlight the

\footnotetext{
72 Jeffrey J. Rachlinski, The "New" Law and Psychology: A Reply to Critics, Skeptics, and Cautious Supporters, 85 CORNELL L. REV. 739, 739 (2000).

73 Christine Jolls et al., A Behavioral Approach to Law and Economics, 50 STAN. L. REv. 1471, 1476 (1998).

${ }^{74}$ Korobkin \& Ulen, supra note 26 , at 1078.

75 Given the savings in time and resources, these heuristics may be "rational" in the sense that they ultimately are more efficient to the decisionmaker than traditional cost-benefit analysis. See PosNER, supra note 17, at 19.
} 
need for an agreement before employment begins. In fact, such an agreement may only be included in the paperwork that employees fill out on their first day of work. An employee might be able to ascertain the existence of such an agreement beforehand, but the employee would have to be aware of the existence of these agreements. Empirical studies have demonstrated that employees often have misconceptions about the basic laws of the workplace-for example, employees wrongly believe in the existence of just cause termination protections. ${ }^{76}$ Although further research is necessary, it is a fair hypothesis to assume that many workers will not even know about arbitration agreements before one is presented to them.

Even if workers do know about arbitration agreements, they may end up ignoring the agreement's expected utility in making calculations about the job at hand. In developing their alternative model of human decisionmaking known as "prospect theory," Daniel Kahneman and Amos Tversky identified the tendency of subjects to "edit out" unlikely outcomes from expected utility calculations. ${ }^{77}$ While this editing allows for simpler and quicker decisionmaking, it also introduces potential irrationalities into the process. $^{78}$ Commentators have noted the likelihood that workers will edit out less salient factors from their decisionmaking process. ${ }^{79}$ This finding reflects common sense: It seems highly doubtful that employees meticulously contemplate the value of all factors in the employment decision, including predispute arbitration agreements. But the failure to factor in the arbitration agreement introduces a potential

\footnotetext{
76 See, e.g., Pauline T. Kim, Bargaining with Imperfect Information: A Study of Worker Perceptions of Legal Protection in an At-Will World, 83 CoRNELL L. REV. 105, 155 (1997) (offering evidence that workers systematically overestimate legal protections against arbitrary and unjust discharge); Pauline T. Kim, Norms, Learning, and Law: Exploring the Influences on Workers' Legal Knowledge, 1999 U. ILL. L. REV. 447, 448 (1999) (concluding that workers do not distinguish between informal norms and enforceable legal rights).

77 See Daniel Kahneman \& Amos Tversky, Prospect Theory: An Analysis of Decision Under Risk, in Choices, Values, AND Frames 17, 29 (Daniel Kahneman \& Amos Tversky eds., 2000) (finding decisionmaking simplification involving discard of extremely unlikely outcomes).

78 Id. at 30.

79 See Samuel Issacharoff, Contracting for Employment: The Limited Return of the Common Law, 74 TEx. L. REv. 1783, 1801 (1996) (discussing people's tendency to remove improbable future risks from their calculations); Cass R. Sunstein, Human Behavior and the Law of Work, 87 VA. L. REV. 205, 243 (2001) (explaining that simplified decisional paths are reason for dismissal of events unlikely to occur).
} 
irrationality to the cost-benefit calculation. ${ }^{80}$ In effect, workers would be assigning a value of zero to the arbitration agreement.

2. Certainty Bias. Imagine yourself as an employee on your first day of work at a new job. A human resources administrator presents you with, among other forms, a predispute arbitration agreement. The administrator tells you that this agreement is company policy and that you must sign it in order to be formally employed. The pros of signing the agreement are all immediate and certain: You can stay at the job, receive a paycheck, and continue with your plans for success. The cons are uncertain: If, perchance, you are fired, harassed, or otherwise injured in violation of the law, you will have to take your claim to arbitration rather than court. Moreover, your alternatives are also uncertain: You may be able to find a job that does not require this form, but you would have to find and secure that job at some future point. ${ }^{81}$ How will the costs and benefits of signing this form (compared with the alternatives) be weighed in your decision about the form?

According to expected utility theory, the costs and benefits of a certain decision will be weighed according to the expected utility of each of the costs and benefits of a particular decision, weighted according to probability. Thus, a 50\% chance of receiving $\$ 100$ should have the same expected utility as the certainty of receiving $\$ 50$. However, a heuristic known as the "certainty effect" leads individuals to place an irrationally high premium on certainty. ${ }^{82} \mathrm{In}$ experiments designed to examine the decisionmaking process, Kahneman and Tversky found that people will value a certain

\footnotetext{
80 Employees' ability to factor arbitration agreements into their cost-benefit analysis - and, in fact, even their ability to conduct a proper cost-benefit analysis-may be affected by their cognitive abilities and their educational background. See Gregory Mitchell, Why Law and Economics' Perfect Rationality Should Not Be Traded for Behavioral Law and Economics' Equal Incompetence, 91 GEO. L.J. 67, 87-98 (2002) (finding that education and training may improve individual's reasoning and increase adherence to prescriptive economic principles).

${ }^{81}$ This hypothetical resonates with commentators. E.g., Grodin, supra note 10, at 3-6; Victoria J. Craine, Note, The Mandatory Arbitration Clause: Forum Selection or Employee Coercion?, 8 B.U. PUB. INT. L.J. 537, 537 (1999).

${ }^{82}$ Kahneman \& Tversky, supra note 77, at 20. Kahneman and Tversky note that the certainty effect was originally introduced by French economist Maurice Allais in 1953. Id.
} 
benefit more highly than they will value an uncertain benefit with the same expected value. ${ }^{83}$

At the decisionmaking point for most employment arbitration agreements, the job at hand is a certain prospect. The employee has already been chosen for employment, and the arbitration agreement is just one of the formalities that must be executed at the beginning of employment. ${ }^{84}$ The alternative to signing the agreement is uncertain: The employee must evaluate the chances of securing another job with a higher expected utility. Even though this job may now have a lower expected utility once the arbitration agreement is factored in, the employee will overvalue that utility given that the utility is a certainty. ${ }^{85}$

Researchers have also found evidence that individuals prefer activities that deliver immediate benefits over those that delay any potential benefits. ${ }^{86}$ For example, researchers found that most subjects preferred a check of $\$ 100$ available immediately to a check of $\$ 200$ that could not be cashed for two years. ${ }^{87}$ In the case of employment arbitration, an employee may have an economically irrational bias toward the current job and its predispute agreement, based on the strong psychic pull of the here and now.

3. Optimism Bias. The term "optimism bias" refers not to an overall sunny disposition, but rather to the general tendency of individuals to underestimate the likelihood that something bad will happen to them. For example, even though applicants for a

${ }^{83}$ Id. For example, in Kahneman and Tversky's study, subjects overwhelmingly chose a $100 \%$ chance of receiving $\$ 3,000$ over an alternative option with an $80 \%$ chance of receiving $\$ 4,000$ and a $20 \%$ chance of receiving $\$ 0$. Id . at 21 .

${ }_{84}$ Some employees are asked to sign arbitration agreements after they have begun working at the job.

${ }_{85}$ It may be argued that in order to perform the proper cost-benefit analysis rational employees would investigate whether the employer would require an arbitration agreement before taking the job. Although I know of no direct research on this point, my intuition would be that most employees do not incorporate this issue into their initial cost-benefit analysis about whether to take the job. See infra notes 86-87 and accompanying text.

${ }^{86}$ See Jon D. Hanson \& Kyle D. Logue, The Costs of Cigarettes: The Economic Case for Ex Post Incentive-Based Regulation, 107 YALE L.J. 1163, 1203-05 (1998) (discussing evidence of immediacy bias).

87 George Ainslie \& Nick Haslam, Hyperbolic Discounting, in Choice Over Time 57, 69 (George Loewenstein \& Jon Elster eds., 1992). Interestingly, the study found that people did not prefer a $\$ 100$ check payable in six years to a $\$ 200$ check payable in eight years. Id. The lack of immediacy likely cooled the irrational preference. 
marriage license correctly estimated that the national divorce rate was $50 \%$, their modal estimation of their own chance of divorce was zero. ${ }^{88}$ College students in another study were six times more likely to respond that they expected their job satisfaction to be above the average of their peers than below the average. ${ }^{89}$ Similarly, respondents perceived themselves to be less likely than the average to be unemployed..$^{90}$ It is apparently human nature to expect oneself to be less likely than others to suffer from misfortune or more likely to experience success. This optimism may extend to the employment relationship: The employee may place an unrealistically low probability on the likelihood that some sort of employment law dispute will arise. ${ }^{91}$

Optimism bias may be one component of a more complex set of responses to uncertainty. For example, another irrationality that may come into play is the "availability heuristic," which concerns the effect of one's pool of knowledge on probabilistic calculations. ${ }^{92}$ In assessing the likelihood of certain events people are unduly influenced by their own pool of personal information. ${ }^{93}$ They overestimate the relevance of certain events or instances that are "available" to their memories in ways that other events may not be. ${ }^{94}$ For example, most people incorrectly believe that homicides and car accidents kill more Americans than diabetes and stomach cancer. ${ }^{95}$

88 Lynn Baker \& Robert E. Emery, When Every Relationship is Above Average: Perceptions and Expectations of Divorce at the Time of Marriage, 17 LAW \& HuM. BEHAV. 439, 443 (1993), cited in Jon D. Hanson \& Douglas A. Kysar, Taking Behaviorism Seriously: The Problem of Market Manipulation, 74 N.Y.U. L. REV. 630, 655 (1999).

${ }^{89}$ See Neil D. Weinstein, Unrealistic Optimism About Future Life Events, 39 J. PERSONALiTY \& Soc. PsYChOL. 806, 810 tbl.1 (1980) (dividing number of optimistic responses by number of pessimistic responses).

${ }_{90}$ See id. (measuring mean comparative judgment of own chances versus chances of others).

${ }_{91}$ See Christine M. Reilly, Comment, Achieving Knowing and Voluntary Consent in Predispute Mandatory Arbitration Agreements at the Contracting Stage of Employment, 90 CAL. L. REV. 1203, 1228-30 (2002) (discussing optimism bias and resulting underestimation of risk).

${ }_{92}$ See Scott A. Moss, Women Choosing Diverse Workplaces: A Rational Preference with Disturbing Implications for Both Occupational and Economic Analysis of Law, 27 HARV. WoMEN's L.J. 1, 14 n.66 (noting that availability heuristic causes people to extrapolate information from what they happen to hear).

${ }^{93} I d$.

94 See Reilly, supra note 91, at 1230-34 (arguing heuristics lead to biases in judgment).

95 Scott Plous, The Psychology OF JUdGMENT AND DECISION MAKING 121-22 (1993). 
Psychology researchers theorize that the basis of this misperception is the "availability" to people's memories, primarily through the media, of instances of car accidents or murders. ${ }^{96}$ Instances of diabetes or stomach cancer deaths receive less attention although they are sadly far more common. ${ }^{97}$ In the case of events like divorce and unemployment, individuals who have not experienced these events may not have vivid stories "available" to their memories and would underestimate the likelihood of such events. If workers have not experienced an employment dispute, either directly or through the experience of someone they know, they may underestimate the likelihood that such an experience would arise. ${ }^{98}$ Conversely, if workers have such an experience in their information pool, they may overestimate the likelihood of such an event recurring. ${ }^{99}$

The effects of the optimism or overconfidence bias seem to extend beyond the scope of one's experience. Instead, this optimism seems to play a strong role in shaping the perceptions of that experience. For example, one study provided a group of law students with factual information relating to a hypothetical lawsuit. ${ }^{100}$ Those students assigned to be counsel for the plaintiffs interpreted the facts as favorable to the plaintiff, while students assigned as defense counsel interpreted the facts as favorable to the defendant. ${ }^{101}$ Thus, even if employees were given information about the potential for employment-related disputes, they might optimistically believe that they would be able to avoid such disputes. This tendency is what researchers refer to as the "confirmatory" or "self-serving" bias. ${ }^{102}$ As

96 Id.

97 Id.

98 See Reilly, supra note 91, at 1232-33 (arguing lack of experience causes employee misjudgments regarding arbitration).

99 One might argue that the increasing publicity about employment disputes would make such disputes "available" to employees. However, as Sarah Rudolph Cole noted in 1996, "Publicity about the use of arbitration to resolve employment disputes and the consequent effects arbitration has on the resolution of discrimination claims is quite limited." Cole, supra note 9, at 481. Although arbitration has received more attention since 1996, it is hard to measure whether knowledge about such agreements has permeated the national consciousness.

100 Linda Babcock et al., Biased Judgements of Fairness in Bargaining, 85 AM. ECON. REV. 1337, 1338-39 (1995); George Loewenstein et al., Self-Serving Assessments of Fairness and Pretrial Bargaining, 22 J. LEGAL STUD. 135, 145-47 (1993).

101 Babcock et al., supra note 100, at 1340; Loewenstein et al., supra note 100, at 151-52.

102 Korobkin \& Ulen, supra note 26, at 1093. 
with marriage and unemployment, people do not appear to enter a job with the expectation that their employment law rights will be violated. It seems reasonable to predict that individuals will assign a smaller probability to the chance of an employment dispute than reality would require. ${ }^{103}$

4. Framing Effects. Numerous studies have shown that the way choices are framed has an effect on how individuals make those choices. This notion may seem like common sense, but framing effects can work in strange and irrational ways. For example, studies of employee investment behavior show that employees will alter their investment strategies based on the choices in front of them. One such study offered employees the choice between a stock fund and a bond fund with different rates of return. ${ }^{104}$ One group of employees was shown the one-year rates of return while another group was shown a simulated distribution of the thirty-year rates of returns for the funds. ${ }^{105}$ Employees shown the one-year rate invested a majority of their money in the bond fund while those shown the thirty-year rates chose to invest almost everything in the stock fund. ${ }^{106}$

All of this is to suggest that our decisionmaking processes are susceptible to influence. We may place undue importance on the facts as presented to us or as highlighted in a set of materials. In providing the arbitration agreement for the employee to execute, the employer chooses how to frame the decision. The employer could tell the employee that the arbitration program offers a chance for employees to save money on legal bills. Or the employer could present the agreement as a mere formality, a part of the set of forms that all employees sign on their first day. An agreement to arbitrate might be part of an employee handbook, or the agreement may not even be given to the employee. Certainly, more research is necessary to determine what kinds of framing employers may engage in and whether these framing devices have any effects. But

103 See Cole, supra note 9, at 480-81 (arguing employees tend to underestimate risk of conflict); Reilly, supra note 91, at 1228-30 (discussing optimism bias and resulting underestimation of risk).

104 Shlomo Benartzi \& Richard H. Thaler, Risk Aversion or Myopia? Choices in Repeated Gambles and Retirement Investments, 45 MGMT. SCI. 364, 374-75 (1999).

105 Id.

106 Id. at 377. 
it certainly would not be surprising to find that employees have different types of reactions to different methods of presenting the arbitration agreement. Such framing effects add another level of irrationality to the cost-benefit analysis.

\section{THE ADVANTAGES OF DEFERRING ARBITRATION DECISIONS}

Before discussing the conclusions we can draw from the models discussed earlier, a brief summary may be in order. When considering arbitration after a dispute has arisen, the employee and employer will agree to submit that dispute to arbitration if the expected value of arbitration is greater than the expected value of litigation. Expressed as an equation, each party would choose arbitration if:

$$
P_{a} * R_{a}-C_{a}>P_{l} * R_{l}-C_{l}
$$

If the parties differ as to their preferred forum, one party will pay the other party to ensure that they both agree to the most efficient forum. Certainly, there is no guarantee that the parties will have the perfect information necessary to ensure an efficient result. But the types of information required-probability of success, potential for relief, and estimated costs-are data that parties and professional players attempt to estimate all the time.

When considering arbitration before a dispute has arisen, the parties must make a different determination. The predispute decision is far more complex, particularly for the employee. The employee must calculate what the potential costs and benefits would be for all potential situations involving prohibited activities. Then the employee must estimate the probabilities that these situations would arise. As noted above, the expression of this decision would be:

$$
\begin{gathered}
{\left[X_{a}(1) *\left(P(1)_{a} * R(1)_{a}-C(1)_{a}\right)\right]+\ldots+\left[X _ { a } ( n ) * \left(P(n)_{a} * R(n)_{a}-\right.\right.} \\
\left.\left.C(n)_{a}\right)\right],
\end{gathered}
$$

as compared with 


$$
\left[X_{l}(1) *\left(P(1)_{l} * R(1)_{l}-C(1)_{\nu}\right)\right]+\ldots+\left[X_{l}(n) *\left(P(n)_{l} * R(n)_{l}-C(n)_{l}\right)\right]
$$

If the agreement is required by the employer, the employee would have to factor in this agreement when comparing the current job with all other potential jobs. Again, such a decision could be expressed as:

$$
\begin{gathered}
J_{j 1}+\left[X_{a}(1) *\left(P(1)_{a} * R(1)_{a}-C(1)_{a}\right)\right]+\ldots+\left[X _ { a } ( n ) * \left(P(n)_{a} * R(n)_{a}-\right.\right. \\
\left.\left.C(n)_{a}\right)\right],
\end{gathered}
$$

as compared with

$$
\left(P_{j 2} *\left(J_{j 2}+{ }^{\prime \prime} 2\right)\right)+\left(D_{j 3} *\left(J_{j 3}+{ }^{\prime \prime}{ }_{j 3}\right)\right)+\ldots+\left(D_{j n} *\left(J_{j n}+{ }_{j n}\right)\right) .
$$

The information needed for these calculations is far more difficult to obtain than the information needed for the simple $(P * R)-C$. And in all likelihood, the employee will find it economically inefficient to consult an attorney or other expert since the costs of obtaining the information will likely be greater than the benefits, and the agreement may well be a condition of employment. Given the impossible task of making an economically rational decision about such an agreement, employees are prone to use decisionmaking shortcuts to make up their mind-shortcuts that may lead to systematically irrational results.

What does this analysis tell us about these agreements? In my view, it tells us that postdispute agreements to arbitrate are much more likely to be based on good information and therefore much more likely to be not only efficient, but also optimal for both sides. Predispute agreements, on the other hand, are more likely to be based on primitive guesswork, or less, on the part of the employee-the worse the information, the greater the chance that the agreements will not be efficient. In addition, the employer is likely to have a significant informational advantage over the employee. Employers may use this advantage to construct inefficient agreements that employees would not agree to if they had perfect information. ${ }^{107}$

107 Keith Hylton has greater faith in the ability of employees to obtain the information 
Of course, there is no general legal requirement that contracts be efficient, nor must parties have good information about the substance of an agreement in order for that agreement to be enforceable. People make contracts all the time involving risk-risk that may be very difficult to calculate. When a member of the public purchases a share of a company's stock, for example, that person may have no idea what the real value of that stock should be. Other players in the market may have access to sophisticated analyses about the company's management, the industry's prospects, and the economy's direction. But this person might have purchased the stock because they liked the company's logo. Similarly, people can buy insurance for events about which they know little in terms of probability. Homeowners' insurance is just one example-how likely are such events as theft, fire, flood, or hurricane? How much should insurance against these events cost? People make ill-informed decisions about risk all the time. Why should we care in this case? ${ }^{108}$

First, I think we generally do care about situations where one party is consistently likely to have an informational advantage over

needed to decide efficiently about predispute agreements. Hylton believes that employees are making a "rational bet" that they will be better off as a result of the agreement and that the parties should be left to abide by the results of their bet. Hylton, supra note 17, at 251. Hylton also argues that employees may be exhibiting "rational apathy" in not attending to the details of the agreement on the grounds that the expected costs of investigation may be too high for the potential benefits gained. See id. at 252. The costs for an individual employee, however, might be high enough that the employee takes a real utility hit, rather than a de minimis loss. In such cases, the employer can take advantage of the economy of scale to extract rents from employees unwilling to challenge the employer's position. See Cole, supra note 9, at 475-76 (discussing advantages to employer in developing standardized employee agreements). Hylton also argues that competition among employers for employees will drive unfair arbitration agreements out of the market. Hylton, supra note 17, at 252-53. If employees do not accurately price those agreements, however, they will not realize the value of such agreements. Thus, an employer who offered a fair agreement would be punished by the market, as employees would undervalue such agreements. Finally, Hylton argues that even if employees can be taken advantage of in the short term, they will eventually realize this and demand less biased agreements (or no agreements) in the future. $I d$. at 253-54. I would agree that, over time, employees will become more aware of the pros and cons of such agreements. Their psychological "availability" will increase, particularly if the media highlights egregious examples of such predispute agreements. Employees may even band together to get more information about such agreements. But in my estimation the time of such awareness has not arrived.

108 See Hylton, supra note 17, at 251 ("It is common in contract settings for one party to know more than the other about some aspect of the deal, and so for the uninformed party to make a statistical bet that he is better off entering the contract despite his informational deficit."). 
another party. While a person need not conduct a thorough analysis of a company's prospectus before buying its stock, federal securities regulation ensures that a vast supply of information is available for those who wish to make use of it. ${ }^{109}$ Moreover, those with special insider information are prohibited from trading. ${ }^{110}$ Insurance companies are heavily regulated by state commissions, in part due to the informational disadvantage of consumers. ${ }^{111}$ Even state lotteries tell buyers that they only have a 1-in-120-million chance of winning the Powerball jackpot. ${ }^{112}$ When there are possible information discrepancies, the law often steps in to ameliorate such discrepancies or their effects.

Second, one of the primary ideological bases for contract law is the notion of Pareto optimality. Two parties will only agree to a contract if they both expect to be better off from it. ${ }^{113}$ Certainly, after the contract has been fully performed, one side may find itself worse off than it expected to be. But economically rational parties will not execute a contract unless they expect the contract to increase their utility. This expectation-that everyone will be better off if this exchange occurs-forms the cornerstone of economic thinking and also provides the normative foundation for economic theory. While the wealth-maximization norm in economics has its fair share of critics, the norm of Pareto optimality is much less controversial. ${ }^{114}$ Its relative scarcity in the real world of policymaking makes it even more attractive when it does surface. ${ }^{115}$ Thus, if parties are not making rational calculations that a certain agreement will make them better off, the normative justifications for contract law are weakened. ${ }^{116}$

109 Securities Act of 1933, 15 U.S.C. § 77a-77aa (2000).

110 SEC Rule 10b-5, 17 C.F.R. § 240.10b-5 (2004).

111 See, e.g., website for John W. Oxendine, Georgia Insurance and Safety Fire Commissioner, at http://www.inscomm.state.ga.us/ (last visited Oct. 1, 2004) (linking to information regarding insurance regulation).

112 See, e.g., Missouri Lottery, Understanding Powerball Chances, at http://www. molottery.com/aboutourgames/howtowin/numbergames/powerball/powerball\$understandin godds.shtm (last visited Sept. 8, 2004) (explaining odds of winning Missouri powerball lottery).

${ }_{113}$ See supra note 17 (defining Pareto efficiency).

114 See PoSNER, supra note 17, at 12 ("Who can quarrel with unanimity as a criterion of social choice?").

115 Id. at 13

116 Of course, some theories of contract law place no reliance on the notion of Pareto 
Third, employment laws provide state-mandated rights to employees. These laws represent a public decision to compensate individuals for certain types of injuries. If employees are signing away important procedural protections for those rights, society has more of an interest than if employees are merely agreeing to lower wages. $^{117}$ The Supreme Court has found predispute waivers of employment law rights to be unenforceable because such rights are deemed to represent a societal entitlement. ${ }^{118}$ The remedial benefits offered by these statutes, along with the deterrence effects of such remedies, are deemed to be part of a "congressional command that each employee be free from discriminatory practices." 119 The Supreme Court has premised its approval of predispute arbitration agreements on the notion that such agreements are not waivers of the underlying substantive rights. ${ }^{120}$ However, a biased predispute agreement to arbitrate effectively acts as a waiver. ${ }^{121}$ Even a slightly biased agreement weakens the effects of the statutory entitlements. Thus, to the extent employees are taking a risk by using incomplete information, they are gambling with their congressional entitlements.

Finally, one has to ask, what is the point of the predispute agreement? What is the "risk" that the agreement is allocating?

optimality. See Barnett, supra note 20, at 271-91 (discussing different theoretical justifications for contract).

117 See Martens v. Smith Barney, Inc., 181 F.R.D. 243, 253-54 (S.D.N.Y 1998) (discussing why individuals may not be permitted to waive rights provided by society through Title VII).

118 Alexander v. Gardner-Denver, Inc., 415 U.S. 36, 51-52 (1974).

Title VII . . . concerns . . . an individual's right to equal employment opportunities. Title VII's strictures are absolute and represent a congressional command that each employee be free from discriminatory practices. Of necessity, the rights conferred can form no part of the collective-bargaining process since waiver of these rights would defeat the paramount congressional purpose behind Title VII. In these circumstances, an employee's rights under Title VII are not susceptible of

Id. prospective waiver.

119 Id. at 51.

120 See Circuit City Stores, Inc. v. Adams, 532 U.S. 105, 123 (2001) (finding arbitration agreements enforceable under FAA does not contravene federal law protecting against discrimination); Gilmer v. Interstate/Johnson Lane Corp., 500 U.S. 20, 27-28 (1991) (finding no inconsistency between policies of Age Discrimination in Employment Act and agreements to arbitrate age discrimination claims).

121 See Hylton, supra note 17, at 230 ("If the arbitral forum is heavily biased in favor of the defendant, then an arbitration agreement may be effectively equivalent to a waiver.”). 
After all, an employee can agree to arbitrate a dispute after it arises. Why constrain that choice beforehand? ${ }^{122}$ When other contracts are made based on poor information, the contract is often intended to hedge the risk inherent in the situation. People buy stocks, for example, to provide capital to a risky enterprise. The company receives funds it could not otherwise acquire (due to the risk), and the stock buyer receives the opportunity to participate in the company's profits. The buyer knows that she has imperfect information, but that risk is part of the reason for the deal. Similarly, insurance contracts are a straightforward hedge against risk; a homeowner buys flood insurance to mitigate the financial harms of a potential flood. But why would parties sign a predispute arbitration agreement? Are the parties hedging a risk? If so, a risk of what? Initially, the predispute agreement is only a "hedge" against litigation; it prevents the possibility that the parties will not agree to arbitrate the dispute later. But both parties will clearly have better information about the costs and benefits of arbitration after the dispute arises. Why not wait until then to decide? Why constrain choice?

\section{Potential Theories For the EFFiciency of PREDisPUTE ARBITRATION AGREEMENTS}

The following section is an effort to answer these questions by explaining why predispute arbitration agreements may provide greater efficiency under certain conditions than postdispute agreements. It is not enough that the predispute agreements lead to generally efficient results if those same results could have been achieved through a postdispute agreement. As an example, let us suppose a world where arbitration costs are always less than litigation and arbitration results are always as equally fair as litigation results. In such a world, it would be efficient for both parties to sign a predispute arbitration agreement. But rational

\footnotetext{
122 As one advocate puts it, "[i]f proponents of arbitration are correct in their belief that it is faster, cheaper[,] and better than the judicial system, then surely employees and their attorneys will opt for arbitration in a voluntary system." Patricia Ireland, President of National Organization of Women, Address before a committee of the National Association of Securities Dealers (June 1997), at http://www.now.org/issues/wfw/nasd-testimony.html.
} 
parties would also always agree to arbitrate their dispute after the dispute arose; there would be no benefit to parties for signing a predispute agreement. ${ }^{123}$

Therefore, in order for predispute agreements to serve some efficiency purpose, they must force some parties into arbitration when they would not have chosen to do so postdispute. Moreover, the agreement must force such parties into a more efficient outcome than they would have reached without the agreement. The following are efforts to describe such conditions, grouped in the categories of (A) ex ante benefits, (B) prevention of irrational arbitration rejection, and $(\mathrm{C})$ the reduction of societal externalities.

\section{A. EX ANTE BENEFITS}

It is perhaps difficult to imagine a scenario that fits our two criteria for predispute agreement efficiency: (1) it would be more efficient for the parties to choose arbitration over litigation to resolve a particular dispute, but (2) at least one of the parties would not choose arbitration without the presence of an arbitration agreement. The Coase Theorem teaches that if arbitration is the more efficient outcome, the parties will bargain and will end up choosing arbitration. Even though one party might have a preference for litigation at the outset of negotiations, the parties would ultimately decide to choose arbitration if arbitration is more efficient. Thus, the Coase Theorem would seem to rebut claims that postdispute agreements will never take place because one side or the other will always prefer litigation after the dispute has arisen. ${ }^{124}$ Even if litigation always offers an advantage for one side, the parties will negotiate around the litigation default option if it is more efficient to proceed to arbitration.

${ }^{123}$ See, e.g., Shavell, supra note 17, at 5 (“[W]hile reduction in costs is an advantage of ex ante [Alternative Dispute Resolution (ADR)] agreements, it is equally an advantage of ex post ADR agreements.").

124 See, e.g., David Sherwyn, Because It Takes Two: Why Postdispute Voluntary Arbitration Programs Will Fail to Fix the Problems Associated with Employment Discrimination Law Adjudication, 24 BERKELEY J. EMP. \& LAB. L. 1, 37 (2003) ("In order for a postdispute voluntary arbitration system to work, both the plaintiff's and the defense lawyer need to conclude that arbitration's benefits outweigh its costs and that arbitration represents the best chance for success for each lawyer.") (emphasis omitted). 
The following five possibilities, however, describe how predispute agreements might offer ex ante benefits by constraining the parties from choosing litigation after the dispute has arisen. In other words, the predispute agreement provides greater efficiency by forcing the parties into an arbitration that is socially efficient but would not be chosen after the dispute arose. In each case, although one of the parties would have a postdispute preference for litigation that could be overcome through negotiation, the overall good is better served by preventing that party from litigating.

1. Spreading the Benefits. If arbitration provides more efficiency as between the parties than litigation, the parties will bargain to go to arbitration. In a postdispute scenario, the employer and employee would negotiate to split the benefits that accrue from choosing arbitration over litigation. The employee and employer might have equally lower litigation costs and thus would not exchange any payment as part of the deal. In other cases, the employer might have significantly greater savings from arbitration than would the employee. In negotiating over the potential forum, each party could bargain to obtain some of the surplus. For example, assume that an employee is threatening to bring a suit against an employer. The employee's costs would be the same in both arbitration and litigation, but the suit would cost an employer an estimated $\$ 10,000$ to litigate but only $\$ 1,000$ to arbitrate. The employee would negotiate with the employer to arbitrate the dispute in exchange for receiving some of the $\$ 9,000$ in savings.

If we assume a world in which arbitration always saves an employer significant costs as compared to litigation fees, then a predispute arbitration agreement would save an employer significant sums. What happens to that money? The employer gets it, but theoretically employees could bargain for that surplus as well. In the predispute world, however, the money cannot be allocated only to those employees who will eventually bring a claim against the employer. Instead, employees have to bargain individually for what they believe is their share of the employer's surplus. If each employee is a potential claimant, then each employee will deserve a share of the surplus. As an example, C\&C Co. has ten employees. Based on the past history of C\&C Co., as well as societal trends, the employees and the employer would predict that two of these ten 
employees will bring claims against the employer during the course of their career. These claims would each cost the employer $\$ 10,000$ to litigate but $\$ 1,000$ to arbitrate. If all employees choose to sign a predispute agreement, the employer will save $\$ 18,000$. Each of the ten employees could therefore negotiate to receive some part of this surplus. Their pro rata share of the surplus, however, would only be $\$ 1,800$. Thus, if the employer distributed all of its surplus equally to the employees, each employee would receive $\$ 1,800$ for signing the predispute agreement. However, if employees did not sign such agreements, two of the employees would be able to negotiate a $\$ 9,000$ payment when they brought their claims, while the other employees would receive nothing.

In this example, the predispute agreement serves as a form of reverse litigation insurance. If you think of litigation as a windfall, and if employees are risk averse, a risk-averse employee might choose a $100 \%$ chance of receiving $\$ 1,800$ to a $20 \%$ chance of receiving $\$ 9,000$. Thus, a predispute agreement might provide better overall utility. Certainly, an employee would have no incentive to voluntarily share his or her settlement with the other employees after a dispute has arisen. By locking in employees ahead of time, the predispute agreement insures that the efficiency gains are spread to all employees, not just those who choose to litigate.

There are several problems with this model. First, the model assumes that the employer passes on all of the cost savings to the employees. Employees, however, are in a much better position to extract this surplus after the dispute has already arisen. As discussed in Part II, it is much harder to calculate the cost savings for a predispute agreement than it is for a postdispute agreement. ${ }^{125}$ The employer and employee will know substantially more about the nature of the claim, and therefore the potential costs, when the claim is on the table. Moreover, individual employees lack the information to know exactly what costs savings a predispute agreement will create. As noted above, the informational difficulties may lead employees to ignore or guess about the factors that would go into a proper cost-benefit analysis of the agreement.

\footnotetext{
125 See supra notes 25-70 and accompanying text.
} 
A second and more disturbing problem is that this "reverse" insurance would act to draw money away from those who are injured and give it to the rest of the employee class. If an employment claim really were like the lottery, this development might not raise concerns. An employment claim, however, stems from an injury inflicted in violation of a legal mandate. Taking money away from the injured to spread amongst the noninjured seems a perverse method of societal distribution. In addition, those in the injured class, at least for employment discrimination claims, are more likely to be members of a protected class: racial or ethnic minorities, women, the elderly, or the disabled. Certainly, the policies underlying the civil rights acts would be undermined by agreements that took money from injured victims of these groups and distributed it to all employees.

Finally, we have assumed that all of the arbitration "surplus" for the employer comes from a savings in the costs of litigation. If some of the surplus comes from a savings in the amount of relief rendered, then the victims are actually paying for the surplus out of their entitlement. ${ }^{126}$ As another example, let us assume DDD, Inc. will save an expected $\$ 10,000$ if a case is taken to arbitration, not in costs saved but in a reduction in the expected award. The expected award from litigation is $\$ 30,000$, and the expected award from arbitration is $\$ 20,000$. This may be due to the bias of the arbitrator, an arbitral limit on certain types of damages, or other factors. Regardless, if an employee knows about this difference, he or she may negotiate with DDD, Inc. to receive the difference in exchange for taking the case to arbitration. After all, the employee is entitled to the expected $\$ 30,000$ benefit under law. Under a predispute arbitration agreement, however, the employee would not be able to bargain for this surplus after the fact; instead, it would accrue entirely to DDD, Inc. Employees might be able to negotiate for the expected "bias" differential ahead of time. The differential, however, would accrue to all employees, rather than exclusively to those who are injured. Injured employees would get only a fraction of the

\footnotetext{
126 See Stephen J. Ware, The Effects of Gilmer: Empirical and Other Approaches to the Study of Employment Arbitration, 16 OHIO ST. J. ON DisP. RESOL. 735, 750 (2001) (noting that if only source of savings from arbitration is lower awards, "then the Gilmer rule undoes, to some extent, the effects of the employment discrimination statute").
} 
$\$ 10,000$ bias differential. This result would obviously undermine the remedial purposes of the employment law protections.

Given these objections, the "spreading-the-benefits" theory fails to provide sufficient efficiency justifications for predispute agreements.

2. Trading a Few Big Claims for Many Small Ones. A more promising justification finds its most prominent proponent in Samuel Estreicher and his "Saturns for Rickshaws" theory. ${ }^{127}$ According to Estreicher, litigation is not a usable entitlement for many employees. ${ }^{128}$ For those employees with low wages, less severe employment law injuries, or less certain litigation outcomes, the costs of litigation may be too high to bring suit. Most employees cannot pay attorneys enough to take the suit for a preset fee, and the potential contingency fees are too small for these claims. Other employees, however, have higher salaries and suffer injuries that may entitle them to compensatory or punitive damages. These employees also benefit from an unpredictable jury system, which could provide a range of damages extending up to sizeable sums. They can readily find attorneys and can often secure large settlements with the threat of litigation. Thus, Estreicher paints a picture of two sets of employees: those with "rickshaws"-claims too small to be litigated —and those with "Cadillacs"—suits which entitle them to significant awards. ${ }^{129}$

As part of his efficiency argument, Estreicher raises the possibility that in some cases an employer might game the system to prevent a claim from going to arbitration, even where it might be efficient to do so. As an example, let us suppose that an employer violates an employee's employment law rights, and as a result the employee suffers an injury of $\$ 1,000$. The costs of litigating the dispute are $\$ 1,000$, and the employee would have an $80 \%$ chance of success. The costs of arbitrating the dispute would be $\$ 200$, and the employee would have a $75 \%$ chance of success. A cost-benefit

127 Estreicher, supra note 33, at 559.

128 Id. at 563.

129 Id. See also Samuel Estreicher, Predispute Agreements to Arbitrate Statutory Employment Claims, 72 N.Y.U. L. REV. 1344, 1357 (1997) ("In short, we have a system in which a few individuals in protected classes win a lottery of sorts, while others queue up in the administrative agencies and face reduced employment opportunities.”). 
analysis reveals that the litigation computation reaches a negative result for the employee: $(.80 * \$ 1,000)-\$ 1,000=-\$ 200$. The arbitration result is much better: $(.75 * \$ 1,000)-\$ 200=\$ 550$. If we assume that the employer has exactly the same costs, the employer would also prefer arbitration to litigation. The expected value of litigation would be $(.80 *-\$ 1,000)-\$ 1,000=-\$ 1,800$, while the expected value of arbitration would be $(.75 *-\$ 1,000)-\$ 200=-\$ 950$. However, if (assuming perfect information) the employer knows that the employee would lose money by bringing the suit, the employer will not agree to arbitration. ${ }^{130}$ Even though it is more efficient for both parties to pursue arbitration, the employee will be unable to sufficiently compensate the employer for choosing arbitration, and the employer will sit tight and wait for the employee to go away. This result of no litigation or arbitration-and a "de facto" award of $\$ 0$ - is obviously the best result for the employer. It is also preferable for the employee, compared against litigation's $\$ 200$ loss. And the employee cannot force the employer into arbitration.

Assuming this situation, it is preferable for the employee to sign a predispute arbitration agreement. In such a case, the employer is locked into arbitration and therefore could not reject the option later. Of course, if litigation costs were a barrier to every employment claim, the employer could sit tight on every claim and therefore would never agree to a predispute agreement. Thus, the tradeoff that makes the predispute agreement palatable to the employer is lower exposure on the claims that could go to litigation. Thus, the employer will have to save costs on litigable claims-potentially through lower awards -in order to balance out the increase in costs for nonlitigable claims. To use Estreicher's metaphor, if some workers are to get the chance to trade their rickshaws for Saturns, ${ }^{131}$ others will have to trade in their Cadillacs.

130 See supra note 35 and accompanying text.

131 "Saturn" refers to cars produced by the Saturn Corporation, a division of General Motors that specializes in mid-priced, consumer-friendly cars. See Saturn Corp., Important Date In Saturn History 1, at www.saturn.com/aboutus2/student/pdf/Full\$Student\$Packet.pdf (last visited Sept. 8, 2004) (describing formation and concept of Saturn Corporation). I must admit that as a former and satisfied owner of a Saturn, I find this metaphor particularly effective. However, Saturns have recently received poor marks from the trade press. Jerry Flint, The Rings Fall Off Saturn, Forbes.com (Jan. 1, 2003), available at http//www.forbes. com/home\$europe/2003/01/01/cz\$jf\$0101flint.html. 
Estreicher's argument is really a form of "reverse insurance" in that it takes from the few (with big claims) and gives to the many (with small claims). ${ }^{132}$ It even has a Robin Hood quality to it since the "few" in his discussion are generally well-paid employees and the "many" are lower-paid employees. As a whole, employees may wish to exchange the possibility of a high litigation award for a better shot at compensation for their smaller grievances.

However, I have several concerns with Estreicher's theory. First, Estreicher assumes that employees with small claims will not engage in any strategic decisionmaking in order to get compensation. Turning back to our example, the employer rejects postdispute arbitration because it knows litigation has a negative net return for the employee (-\$200). Thus, the employer assumes the employee will not pursue her claim. The employee, however, would know that litigation also has a negative net return for the employer-a much more significant one $(-\$ 1,800)$. Might an employee then decide to play a game of litigation "chicken"? In other words, the employee would go forward with the claim, even though it is a losing proposition, because she would expect the employer to blink first and offer a settlement or agree to arbitration. It might be a risky strategy, since it might end up with a $\$ 200$ loss, but the employee would know it was in the employer's best interest to settle. Even if the employer paid only $\$ 201$, the employee would be better off by $\$ 1$ and the employer would be better off by $\$ 1,599$. Estreicher might argue that employees with small claims could not even get their claims filed, since plaintiffs' attorneys would not be willing to sign on to this strategy. Employees, however, can file discriminationrelated charges with the Equal Employment Opportunity Commission (EEOC) for free. ${ }^{133}$ As other commentators have pointed out, employers may be willing to settle even baseless claims in order to avoid the costs of an EEOC investigation and potential lawsuit. ${ }^{134}$

${ }_{132}$ I call it "reverse insurance" since insurance takes from the many and gives to the few.

133 U.S. Equal Employment Opportunity Commission, Filing a Charge of Employment Discrimination, at http://www.eeoc.gov/charge/overview\$charge\$filing.html (last visited Sept. 9, 2004).

134 David Sherwyn et al., In Defense of Mandatory Arbitration of Employment Disputes: Saving the Baby, Tossing out the Bath Water, and Constructing a New Sink in the Process, 2 U. PA. J. LAB. \& EMP. L. 73, 82-83 (1999). 
Second, in order for Estreicher's model to make economic sense for employees, there has to be some set of cases that would net the employee a positive return in arbitration but a negative return in litigation. But if even meritless suits have value in the current system, then how many claims fit this category? In other words, for how many claims is there a smaller net benefit to pursuing a strategy of settlement and litigation rather than just dropping the suit entirely? This question is largely an empirical one, and it depends on the cost differences between arbitration and litigation in employment cases, and the distribution of values for the various employment law claims. Estreicher's hypothesis-that a number of low-value claims are being stymied-may be correct, but there is insufficient data to know what this number might be. If the number is small, then employees might end up trading in more Cadillacs than rickshaws.

Third, Estreicher's clever metaphor for his system masks part of the underlying dynamic. By labeling high-value claims as "Cadillacs," and low-value claims as "rickshaws," Estreicher makes his new system of "Saturns" seem more egalitarian. But why do some claimants have high-value claims and others have low-value claims? One reason may be their incomes: Those with higher salaries will have greater damages for lost wages and future compensation. But another reason may be the severity of their claim. An employee who is fired, for example, will generally have a more significant injury, and therefore a greater damages claim, than an employee in the same position who was not promoted. An employee who suffered continual and degrading sexual harassment may be entitled to substantial compensatory and punitive damages. These employees have higher claims for a reason: Their injuries are worse. Thus, an employee is not necessarily driving a "Cadillac" because she has a cushy job; she may have just sustained grievous damages. ${ }^{135}$ This system begins to look like the "spreading the benefits" solution; it takes a chunk from those with significant claims and spreads it around to those with small or no claims.

\footnotetext{
135 The choice of "Cadillac" has particular rhetorical effects. It symbolizes flashy, conspicuous consumption. In his well-known description of welfare fraud, former president Ronald Reagan described a "welfare queen" who drove to pick up her checks in a Cadillac. DAVID ZuCCHINO, MYTH OF THE WELFARE QUEEN 64-65 (1997).
} 
Finally, Estreicher's description of arbitration results seems to assume that all workers would be covered by the system of predispute arbitration agreements. Estreicher notes that employers do not know ahead of time who will be claimants and, therefore, should want to include all employees in the agreement. ${ }^{136}$ However, if Estreicher is correct in assuming that well-paid employees are the ones with the high-value claims, the employer will have an incentive to get highly paid employees into arbitration and leave poorly paid employees out. The employer has no obligation to offer the predispute agreement to all employees. So why would the employer not just offer the predispute agreement to those employees likely to have "Cadillacs"? Indeed, one would expect different employers to have different incentives. Employers with a highly paid, white collar workforce would have the incentive to adopt a predispute agreement, while those with a lower paid, less legally aware workforce would not. If this happens, we would be trading a Cadillac-and-rickshaw system for a Saturn-and-rickshaw system.

Ultimately, I think that Estreicher's ideas would find their best fulfillment in a system of court-supervised arbitration or even labor courts. Such a system would be mandatory and thus would not allow for the opt-out possibilities described above. It would have a uniform set of required procedures, which would eliminate employer opportunism in the design of the system. At the same time, it would utilize many aspects of arbitration that Estreicher finds so attractive: lower costs, quicker decisions, and better access for poorer claimants. Such system may eventually be created. In the meantime, it is difficult to say whether private arbitration agreements have implemented Estreicher's "Saturns for rickshaws" vision. $^{137}$

136 Estreicher, supra note 33, at 568.

137 Id. Steven Shavell makes a variation on Estreicher's argument by noting that predispute arbitration could be constructed to encourage more employment-related suits by subsidizing the costs of bringing an action. Shavell, supra note 17, at 7 . Shavell posits a manufacturing example in which precautionary costs are trivial, but the costs of bringing a suit are extremely high-higher, in fact, than the expected return of the suit. Id. Thus, the precautionary measures would not be taken since suits would be too costly to bring. Id. at 7 n.10. A process that allowed the buyers to bring a suit inexpensively would encourage the seller to make the inexpensive precautions. As Shavell admits, such an ADR system would effectively have to "encourage[] suit (for example, by subsidizing it)." Id. at 7. Employees and employers could create an arbitration agreement that provides cheaper costs for employees 
3. Eliminating or Reducing Precautionary Costs. Another potential for ex ante efficiency gains would come from the reduction of precautionary measures that an employer might take to prevent employment law violations. As discussed earlier, Keith Hylton has explained how the potential for litigation may induce employers to make efforts to prevent such claims from arising in the first place. ${ }^{138}$ Such efforts involve costs. If these precautionary efforts are sufficiently expensive, and litigation is expensive for both the employer and employee, an employer may wish to "buy out" an employee's employment law rights ahead of time. In this way, the employer can refrain from taking precautions and not worry about litigation. The employee is satisfied because she receives more in expected value than she would receive by keeping the potential causes of action. ${ }^{139}$ Steven Shavell has made a similar point. ${ }^{140}$

Essentially, Hylton's argument for predispute agreements is the same as his argument for predispute waivers: Parties may decide that it is more efficient to agree ahead of time to bar or water down claims rather than allow claims to be litigated once they arise. ${ }^{141}$ As Hylton points out, a biased arbitration agreement may serve the same ends as a waiver-in both cases, the plaintiff is effectively barred from pursuing compensation for her claim. ${ }^{142}$ But Hylton does not share the same aversion to waivers as the Supreme Court. Instead, Hylton believes that waiver agreements can enhance the joint wealth of the parties; therefore, parties should be permitted to waive their rights. ${ }^{143}$ As he notes: "The existence of a biased arbitral forum, rather than being a sign of contract failure, may be

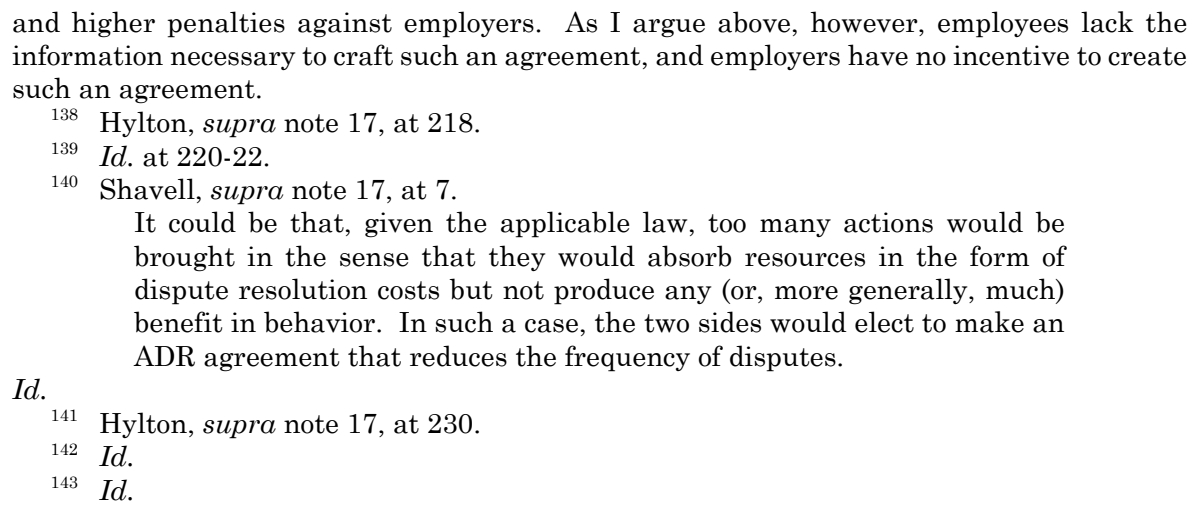


evidence that the parties would have chosen to enter into a waiver agreement had that option been legally available."144

Certainly, it is theoretically possible for two parties with perfect information to reach efficient agreements to waive their prospective disputes or subject their disputes to an arbitral forum. As discussed in Part II, however, I have substantial doubts that employees ever have the kind of information they would need to make such agreements. ${ }^{145}$ Hylton notes that he makes "rather heroic assumptions" regarding "the parties' abilities to foresee events and to calculate the costs and benefits of various decisions." ${ }^{146}$ However, Hylton has greater faith in the parties' ultimate ability to get the information they need for these decisions. I discussed these differences at greater length in Part II. ${ }^{147}$

I also question another of Hylton's assumptions: that employers could eliminate significant precautionary costs if allowed to waive or water down employment law claims through arbitration. The notion of precautionary costs is familiar from the realm of negligence, where Learned Hand's famous $B<P L$ formula dictates that negligence only occurs when the potential for damage exceeds the costs of precautions. ${ }^{148}$ If the burden of precautionary costs is greater than the damage those costs are designed to prevent, then it is inefficient to take such precautions, even if injuries result. Negligence, however, is essentially the law of accidents: The injurer has no intention to injure the victim. Employment law, on the other hand, generally concerns intentional acts: discrimination, harassment, or failure to meet some minimum standard of pay or workplace safety. What exactly would the "precautions" be in the employment law context? Perhaps employee monitoring, workplace training, and human resource personnel could be considered such costs. But these are all efforts to eliminate or mitigate intentional acts. Society understands that a certain level of manufacturing imperfections is inevitable and even necessary (at least in the short

144 Id.

145 See supra note 55 and accompanying text.

146 Hylton, supra note 17 , at 226.

147 See supra note 86 and accompanying text.

148 United States v. Carroll Towing, 159 F.2d 169, 173 (2d Cir. 1947); see also PosnER, supra note 17, at 168 (citing Judge Hand's negligence formula). 
run), but we would prefer a world entirely without racial or age discrimination. Sexual harassment is not an inevitable side effect of productive enterprise.

Ultimately, my main concern with Hylton's argument is his belief that the information difficulties can be overcome. ${ }^{149}$ Even if such difficulties could be overcome, however, I question whether Hylton's precautionary costs would ever be so significant as to warrant a waiver or a biased arbitration agreement, especially given society's distaste for discrimination. ${ }^{150}$

4. Stronger Deterrence Through More Accurate Adjudication. The flip side of Hylton's "reduction of precautionary costs" argument is that arbitration could actually heighten precautionary costs by adjudicating certain claims more effectively. Under this scenario, discussed by Shavell ${ }^{151}$ as well as Drahozal and Hylton, ${ }^{152}$ a predispute arbitration agreement will be efficient if (a) there is a potential for breach of contract which will save one party money but make the other party worse off; (b) courts are unable to detect or punish such breaches properly, while arbitrators can do so more effectively; and therefore, (c) without an arbitration agreement, the receiving party will only pay the value of contract as breached (if at all), while with an arbitration agreement, the party will be willing to pay for the value of full performance. Under this scenario, the parties will act more efficiently if they are able to enforce a predispute arbitration clause. Essentially, the argument is this: If parties can create a system that will better enforce their contractual obligations, then it is efficient to allow them to do so. ${ }^{153}$

\footnotetext{
149 See Hylton, supra note 17, at 250-54 (noting that information asymmetry is not substantial problem).

150 Cf. Mary Ann Case, Developing a Taste for Not Being Discriminated Against, 55 STAN. L. REV. 2273, 2274 (2003) (describing author's "extremely strong taste for not being discriminated against").

151 Shavell, supra note 17 , at 5-6.

152 Christopher R. Drahozal \& Keith N. Hylton, The Economics of Litigation and Arbitration: An Application to Franchise Contracts, 32 J. LEGAL STUD. 549, 551-61 (2003).

${ }_{153}$ See Shavell, supra note 17, at 5-6 (arguing that alternative dispute resolution may cause changes in parties' behavior that increases value of their contractual relationship). Shavell uses the example of two parties contracting for the sale of some good or service. Id. at 6 . The value of good performance to the buyer is $\$ 1,000$, while the value of substandard performance is $\$ 500$. Id. Full performance will cost the seller $\$ 400$, but substandard performance will cost $\$ 300$, saving him $\$ 100$. Id. In this example, both parties are better off if substandard performance can be discouraged, but the seller will engage in substandard
} 
In theory, such a situation could arise in the employment context. For example, we would have to assume that X Co. could prevent employee harassment relatively cheaply, but it has no incentive to do so because courts have consistently declined to find X Co. guilty of harassment. ${ }^{154} \mathrm{X}$ Co., however, realizes that employees hate harassment and will be more productive on the job if they are not subjected to it. Thus, X Co. agrees to set up a generous arbitration agreement with savvy arbitrators who will be able to root out harassment. This system will compel the company to take the precautions necessary to prevent the harassment in the first place.

The hypothetical above displays one reason why the "better deterrence" argument may be inapplicable in the employee context. The example posited by Shavell assumes that parties will be "locked in" to the contract and will be unable to draw on past relations. ${ }^{155}$ The threat of arbitration is necessary to compel the one party not to shirk its contractual duties. But if the parties contemplate a series of contracts instead of just one contract, then the potential shirker will choose not to shirk in order to maintain the relationship. Similarly, in the employment context, the employer need not construct a superresponsive arbitration system in order to create the proper precautionary incentives. The employer can instead simply enact the precautions in order to retain employees and spur them to greater production. After all, the employer knows that if employees are harassed, they are free to leave. Adding a level of superarbitration to enforce antiharassment measures would create an unnecessary cost.

Additionally, it seems unlikely that employees and employers are forming these agreements in order to increase the deterrence of statutory violations. First, if employees were eager for more deterrence, they would presumably be the more active party in

production if the chance of getting caught is low. Id. If arbitrators are much better at detecting substandard performance than courts, then both sides would be better off if they agreed to arbitration at the onset of the agreement. Id. The seller would not agree to postdispute arbitration, since at that point he or she wants to avoid detection. Id.

154 We may assume that the courts do a poor job of uncovering harassment, but the assumptions do not really change if we assume that courts just have a restrictive definition of harassment.

${ }^{155}$ See Shavell, supra note 17, at 6 (discussing how alternative dispute resolution may induce beneficial behavior). 
pursuing such agreements. Employers, however, seem to be the ones pushing for such agreements. ${ }^{156}$ Second, arbitrators are not likely to be more accurate in assessing the validity of statutory claims than courts. In their article on arbitration in the context of franchise agreements, Drahozal and Hylton emphasize the benefits of having specialized arbitrators interpret complicated or indefinite contractual terms. ${ }^{157}$ The arbitrators employed in the collectivebargaining context are also thought to possess insight and experience that enable them to better manage disputes between unions and employers. ${ }^{158}$ In both cases, however, the arbitrator is interpreting (and, over time, reinterpreting) provisions of a particular contract. ${ }^{159}$ In the nonunion setting, however, arbitrators are instead primarily called upon to interpret statutes, regulations, and other provisions of law. Arbitrators do not have the same type of information advantage over the law that they do over a particular contract. In fact, one frequent criticism of nonunion employment arbitration is that arbitrators do not properly apply the law. ${ }^{160}$ The lack of published arbitral opinions makes arbitration outcomes even more uncertain. Overall, arbitration would seem to be a less certain route for enforcement, which decreases, not increases, efficiency. ${ }^{161}$ Third, as I discussed earlier, even if it is possible, as Estreicher argues, that arbitration increases the number of claims brought

156 See, e.g., Steven A. Holmes, Some Employees Lose Right to Sue for Bias at Work, N.Y. Times, Mar. 18, 1994, at A1 (discussing how employers are requiring employees to sign predispute arbitration agreements).

157 Drahozal \& Hylton, supra note 152, at 558.

158 See, e.g., United Steelworkers of Am. v. Warrior \& Gulf Navigation Co., 363 U.S. 574, 582 (1960) ("The ablest judge cannot be expected to bring the same experience and competence to bear upon the determination of a grievance [as an arbitrator], because he cannot be similarly informed.").

159 Even when such arbitrators are determining whether an employee was fired for discriminatory motives, they are determining whether the contractual for-cause provisions have been violated rather than whether Title VII has been violated. See Martin H. Malin \& Robert F. Ladenson, Privatizing Justice: A Jurisprudential Perspective on Labor and Employment Arbitration from the Steelworkers Trilogy to Gilmer, 44 HASTINGS L.J. 1187, 1205 (1993) ("The arbitrator at all times . . . is interpreting and applying the contract.").

160 See, e.g., Cole v. Burns Int'l Sec. Servs., 105 F.3d 1465, 1477 (D.C. Cir. 1997) ("[T]he competence of arbitrators to analyze and decide purely legal issues in connection with statutory claims has been questioned.").

161 See Drahozal \& Hylton, supra note 152, at 559 ("Indeed, arbitration may reduce the deterrence benefit if the parties are uncertain as to how the arbitral forum will interpret contractual terms.”). 
against the employer, those claims would be smaller and would not necessarily increase the deterrence of prohibited activity. ${ }^{162}$ Overall, although arbitration may provide greater deterrence in other contractual contexts, it does not appear likely to do so in the employment context.

5. Economies of Scale. Another potential justification for a predispute agreement could be an economies-of-scale argument. Developing a system of arbitration incurs costs. The employer must first decide whether it would prefer arbitration to litigation-a decision that should require some information gathering and processing. Then the system must be developed: the procedural rules, the potential pool of arbitrators, the locations for the arbitrations, and many other details. Generally such development will require the assistance of counsel. Once the system is constructed, the employer must establish some method of administering its processes. Employees must perform such duties as accepting forms, arranging pre-arbitration meetings, and maintaining the arbitrator pool, or an outside agency must be paid to do these things. In many ways, the employer is responsible for creating and maintaining its own system of justice and must provide many of the services that public employees provide in the court system.

It would be difficult for an employer to develop a system of arbitration after a dispute has arisen. The employer would have to pour resources into a potential system while at the same time pursuing litigation. Under the predispute system, the employer knows that resources devoted to developing the arbitration system will be fruitfully spent. In addition, each employee might have his or her own set of requirements before agreeing to the arbitration. Since each employee would have veto power over the arbitration, the parties might spend a good deal of time haggling over the details. Moreover, if only a few employees eventually opted to choose arbitration, the employer could not spread its costs over a large pool of disputes. It might not make economic sense for an employer to

162 See supra notes 151-55 and accompanying text. 
provide for arbitration if it could not guarantee that all its disputes will be funneled through that system. ${ }^{163}$

There are two potential responses to this economies-of-scale difficulty. First, an employer could develop a system of arbitration but only ask employees to agree to it after the dispute has arisen. As noted in Part II, if arbitration is more economically efficient than litigation, the parties will bargain and ultimately agree to it. ${ }^{164}$ The employee might require some form of compensation in return for agreeing to the arbitration, but the employer could provide the compensation and still be better off. Nothing prevents an employer from developing an efficient system of arbitration and proposing its use after the dispute has arisen. Second, the costs of developing an arbitration system may be going down as more groups provide "offthe-rack" arbitration processes. It may be easier and less expensive for an employer to simply sign on with a group like the American Arbitration Association and adopt its rules, procedures, and pool of arbitrators. Employees and their representatives are also more likely to know about a system developed by a national organization and may therefore be less concerned about the fairness of the proceedings. Commentators have also proposed their own versions of a uniform or model arbitration procedure for parties to use. ${ }^{165}$ These developments are all likely to reduce the costs required in developing an arbitral system.

Nevertheless, employers may be hesitant to invest any funds in an arbitral system that employees will not embrace. It is possible that employees could reject arbitration even if it is in their economic best interest.

B. PREVENTION OF IRRATIONAL POSTDISPUTE ARBITRATION REJECTION

A number of commentators argue that parties will never agree to postdispute arbitration because plaintiffs and defendants have

\footnotetext{
163 See Estreicher, supra note 129, at 1358-59 (arguing that dispute-resolution system is public good, which must be provided on collective basis to be cost-effective).

164 See supra notes 31-42 and accompanying text.

165 See, e.g., Sherwyn et al., supra note 134, at 125-28 (setting forth Model Arbitration Act for employment discrimination claims).
} 
different sets of incentives. ${ }^{166}$ One forum will always have advantages for one side that are disadvantages for the other. However, economic theory teaches that the parties will not be stuck with the default option if another option is more efficient. Instead, the parties will bargain to reach the most efficient alternative. Thus, if the employee would prefer litigation but the employer would choose arbitration, the parties would bargain to reach the most efficient result. If arbitration is more efficient, the employer will provide some incentive for the employee to agree to it; if litigation is more efficient, the employee will reject the employer's offer and stay with the default setting. ${ }^{167}$

Of course, not all transactions operate as smoothly in practice as they do in theory. Part II described why predispute arbitration agreements may have trouble meeting the "perfect information" requirement of the Coase Theorem. ${ }^{168}$ Postdispute agreements are less complicated, and the necessary information is more attainable. However, informational problems could also arise in the postdispute context. For example, employees and their representatives could overestimate the degree of employer bias that arbitrators would exhibit, leading them to undervalue the arbitration option. Or employers might overestimate their chances of success before a jury, leading them to overvalue litigation. Looking at all the factors, the parties could have less than perfect information about the probability of success in each forum $\left(P_{l}\right.$ and $\left.P_{\alpha}\right)$, the likely relief granted in each forum $\left(R_{l}\right.$ and $\left.R_{\alpha}\right)$, and the costs of litigating in each forum $\left(C_{l}\right.$ and $\left.C_{\alpha}\right)$. In fact, parties will most certainly lack perfect information about these factors. If both parties had perfect information about $P_{l}, R_{l}$, and $C_{l}$, they would be able to settle every time.

Of course, as noted in Part II, a large percentage of cases do settle. ${ }^{169}$ Additionally, the information available at the postdispute

\footnotetext{
166 See, e.g., Sherwyn, supra note 124, at 37 ("Invariably, what is advantageous to one side is disadvantageous to the other.").

167 Thus, it is insufficient to simply assert that postdispute arbitration agreements will never take place because one side will always prefer litigation to arbitration. Contra id. at 63 . While both parties may begin with different preferences, if they have perfect information, they will eventually reach a bargain to use the most efficient forum.

168 See supra notes 36-45 and accompanying text.

169 See supra note 50 and accompanying text.
} 
stage is certainly better than the information at the predispute stage. Nevertheless, if parties routinely either lack the appropriate information or make false assumptions about that information, they may routinely make inefficient decisions. In the employment context, parties may routinely make inefficient decisions not to choose postdispute arbitration based on a lack of data or on misinformation about arbitration and litigation. If choosing arbitration is always or generally the most efficient option, then predispute arbitration agreements may actually lead to more efficient results. The parties might be choosing the most efficient result in the dark, but they would be getting there nonetheless.

What might lead parties to reject postdispute arbitration inefficiently? One potential scenario is that employees and their attorneys might overestimate their likelihood of success in litigation and underestimate their likelihood of success before an arbitrator. Such misperceptions could be based on several factors. First, employees and their representatives might lack information about the arbitral process. Arbitration is a private form of dispute resolution, and the results are generally kept between the parties. "Hard" data, such as information about an arbitrator's record of adjudication, or "soft" data, such as information about the arbitrator's personal quirks and biases, may be hard to find or unavailable. In the absence of information, employees and their representatives might conclude that arbitration is more employerfriendly than it actually is. They would therefore demand a higher price to accept it - a price that the employer would find inefficient.

Second, employees and their representatives might be subject to some of the decisionmaking heuristics described in Part II. ${ }^{170}$ For example, employees might suffer from optimism bias in perceiving their likelihood of success in litigation. ${ }^{171}$ They might focus on the likelihood that they will win the maximum amount of damages at trial and irrationally discount their likelihood of failure, as well as the costs of trial. Just as employees can be overly optimistic about their likelihood of termination, they can be overly optimistic about their likelihood of litigation success. Moreover, parties may be

170 See supra notes 72-104 and accompanying text.

171 See supra notes 88-103 and accompanying text. 
subject to the "self-serving" bias, a term for the tendency of parties to interpret facts and events in a way to confirm their preexisting beliefs. ${ }^{172}$ This bias leads to a divergence between plaintiffs and defendants over the likelihood of the claim's success. ${ }^{173}$ This bias could lead plaintiffs and defendants to overvalue their chance of success in litigation, thereby skewing the results of their comparison with arbitration. ${ }^{174}$

In addition, the behavioral characteristic known as the "endowment effect" might affect employee perceptions. The endowment effect refers to the psychological phenomenon in which individuals value what they have more than what they do not have. ${ }^{175}$ In a famous experiment, researchers gave half of the participants a mug. ${ }^{176}$ The researchers then independently asked those with the mug how much money they would want for it and asked those without the mug how much they would pay for it. ${ }^{177}$ Those with the mugs wanted significantly more for the mugs than those without the mugs were willing to pay. ${ }^{178}$ The researchers concluded that there was an endowment effect-people valued the mug they had more than the mug they did not. ${ }^{179}$ In other words, people will require more money to part with something than they would pay to get it in the first place. ${ }^{180}$

The endowment effect causes problems for economic theory because economics assumes that a person's utility for a certain good

172 See supra notes 100-03 and accompanying text.

173 See Korobkin \& Ulen, supra note 26, at 1094 ("Evidence of the self-serving bias in the analysis of lawsuits suggests ... that plaintiffs (and defendants) will systematically anticipate their trial prospects as being better than defendants (and plaintiffs) believe.").

174 Plaintiffs might also overvalue their chance of success at arbitration, but the upside of litigation is generally seen to be higher. See Estreicher, supra note 33, at 563 (discussing high litigation prospects as "Cadillacs" and arbitration prospects as "Saturns").

175 Daniel Kahneman et al., Experimental Tests of the Endowment Effect and the Coase Theorem, 98 J. POL. ECON. 1325, 1325-28 (1990).

176 Id. at $1330-32$.

177 Id.

178 Over the course of four iterations of this study, buyers were willing to pay a median of between $\$ 2.25$ and $\$ 2.50$ for the mug, while sellers were willing to part with the mug for a median of $\$ 5.25$. Id. at 1332 .

179 Id. at 1342 .

180 Numerous other experiments, some conducted outside the laboratory, have found similar evidence of the endowment effect. See, e.g., Russell Korobkin, The Endowment Effect and Legal Analysis, 97 Nw. U. L. REV. 1227, 1232-35 (2003) (showing endowment effect exists in hunters' valuation of environmental changes and in residents' valuation of air visibility). 
or status does not vary based on context. The Coase Theorem is based on the premise that parties will bargain to reach the most efficient result-no matter which party is endowed with the initial legal entitlement. ${ }^{181}$ However, if people value a good or entitlement more highly simply because they possess it, such entitlements will be "stickier" than economic theory would predict. The initial assignment of the good or right may be more difficult to bargain about because the holder will be less willing to part with it. ${ }^{182}$ Therefore, the endowment effect could complicate our model for postdispute arbitration agreements. Employees are "endowed" with the right to take their case to court. Thus, when asked to choose between arbitration and litigation, employees may place a higher value on litigation since they have the right in hand. The endowment effect complicates our expectation that employers and employees will be able to bargain to reach the most efficient result.

The lack of information, coupled with potential behavioral tendencies, may dampen or completely quash efforts by parties to reach postdispute arbitration agreements. Particularly when combined with the start-up costs necessary to arbitrate, these factors may lead to litigation when arbitration would be the more efficient result. Although we do not know how many parties agree to postdispute arbitration, limited studies and anecdotal evidence indicate that such agreements are rare in the employment context. ${ }^{183}$ However, if there are in fact only a small number of parties who agree to arbitration after a dispute has arisen, there are several

\footnotetext{
181 See supra note 36 and accompanying text.
}

182 One unresolved question is whether the increase in utility that apparently flows from having an entitlement should be counted as true utility. In other words, if I would pay $\$ 2.50$ to buy the mug but would require $\$ 5.25$ to part with it, is the mug worth $\$ 2.50$ or $\$ 5.25$ to me in terms of utility? This problem is not as important in the litigation-arbitration context, since both litigation and arbitration are simply means to an end and not intrinsically valuable. Plaintiffs, however, may put a value on having "their day in court," which could be exacerbated by the endowment effect.

183 David Sherwyn studied the arbitration program available through the Illinois Human Rights Commission (IHRC) from 1994 to 1998. Sherwyn, supra note 124, at 61. Although the Commission did not keep precise records of the number of parties using the arbitration program, Sherwyn surmised (using available records and anecdotal evidence) that somewhere between zero and $1 \%$ of the claims filed with the IHRC went to arbitration. Id. at 62 . A similarly small number used the IHRC's mediation program. See Estreicher, supra note 33, at 567 (arguing that underlying incentives usually prevent parties from accepting postdispute arbitration when offered by opposing party). 
possible explanations for this. First, the parties might be acting efficiently, and arbitration might not provide the cost savings that its proponents proclaim. Second, the start-up costs may be too high for parties to pursue arbitration on an ad hoc, postdispute basis. Third, parties might lack the information to properly evaluate the postdispute arbitration possibilities, and they may make improper assumptions about the costs and benefits of arbitration and litigation. Finally, the parties could be irrationally rejecting arbitration based on behavioral heuristics.

Although it is impossible to know at this point why postdispute agreements are rare in the employment context, one potential reason-a lack of information about arbitration-may not be a longterm impediment. As noted in Part II.A, ${ }^{184}$ the information necessary to evaluate a postdispute arbitration agreement is the type of information that attorneys must evaluate all the time. Not every case settles, but attorneys must constantly assess the $P, R$, and $C$ of litigation to determine when and at what price it makes sense to settle. Currently, however, it is difficult to determine the $P, R$, and $C$ of arbitration. Arbitrations are generally private, and parties can create their own unique systems, thus making comparisons difficult. As organizations like the American Arbitration Association become more popular, however, arbitration processes and procedures will become more of a known quantity. ${ }^{185}$ Moreover, these groups are endeavoring to provide more information about the results of arbitrations (in redacted form) so that evaluations of arbitrators themselves can be made. ${ }^{186}$ As arbitration becomes a more popular option, more information will be available, the process will have greater transparency, and parties will be able to make better decisions. ${ }^{187}$

184 See supra notes 25-30 and accompanying text.

185 See, e.g., JAMS, JAMS Guide to Dispute Resolution for Employment Programs and Sample Clause Language (Aug. 2002), at http://www.jamsadr.com/rules/employment\$clauses. asp (outlining steps for employment dispute resolution program).

${ }_{186}$ See, e.g., American Arbitration Association, American Arbitration Association's Employment Awards Database, at http://www.adr.org/AAAAwards/ (containing redacted awards from employment cases, but available only to members).

187 Of course, one reason arbitration may become more popular is the increasing number of predispute agreements. In the absence of predispute agreements, the initial costs of developing and popularizing postdispute arbitration might be prohibitive. Thus, there is something of a "path dependence" to litigation: Because litigation is (currently) the option 
Moreover, there is reason to doubt that behavioral heuristics are leading to a significant number of inefficient decisions in the postdispute context. Certainly, the optimism bias might affect individual plaintiffs, and the endowment effect might lead to a plaintiff preference for litigation. But in the context of most postdispute situations, the employee-plaintiff will have the advice of counsel. Attorneys are regular and repeat market participants. Unlike occasional participants, who fall back on heuristics to deal with uncertain and unfamiliar decisions, attorneys must make rational calculations in order to be successful in their practice. In the predispute context, the employee generally will not have the advice of counsel. Without such assistance, the employee is more likely to fall back onto heuristics in making a decision.

Attorneys are certainly subject to optimism bias, self-serving bias, and the endowment effect. They might therefore demand too high a price for agreeing to postdispute arbitration. These biases, however, also affect attorneys' decisions to settle cases. Thus, decisions not to go to arbitration should be no more systematically inefficient than decisions not to settle. If there are any particular inefficiencies in the postdispute arbitration context, I would suspect they stem from attorney prejudices about arbitration based on lack of information. One would not be surprised to find plaintiffs' attorneys suspicious of arbitration agreements. In fact, a recent survey of Chicago employment attorneys found that both plaintiffs' and defense attorneys thought arbitrators were biased in favor of the other side. ${ }^{188}$ There are, of course, a number of explanations for this data: One side is wrong, one side is lying, or both sides are overly pessimistic. But both sides might also be ignorant. We distrust what we do not understand. As I will discuss further in Part IV, courts and legislatures could take steps to eliminate some of the

created by society, more people use it, and there is more information generated about it than any potentially more efficient alternative. For more on path dependence, see generally PAUL Krugman, Peddling Prosperity (W.W. Norton \& Co. 1994). But see Stan Leibowitz \& Stephen E. Margolis, Policy and Path Dependence: From QWERTY to Windows 95, 18 REGULATION (1995), available at http://www.cato.org/pubs/regulation/reg18n3d.html (arguing economic motives make path dependence inefficient and unlikely in competitive market).

188 Sherwyn, supra note 124, at 42. Both groups of attorneys agreed, however, that judges favor employers and juries favor employees. Id. 
potential inefficiencies caused by a lack of information. ${ }^{189}$ But as I noted earlier, I do not think this problem is as severe, in terms of its efficiency consequences, as the information problem in the predispute context. ${ }^{190}$

C. REDUCTION OF SOCIETAL EXTERNALITIES (OR GREATER SOCIETAL EFFICIENCY)

A third potential argument for predispute arbitration agreements is that they reduce externalities caused by litigation and thereby increase societal efficiency. Here I discuss two versions of this argument: (1) predispute agreements increase efficiency by watering down employment law claims, and (2) predispute agreements increase efficiency by reducing societal litigation costs.

1. Diluting Employment Law Claims. Thus far we have assumed that it is efficient for employees to have the legal protections to which they are entitled. If employment law claims represent a net societal inefficiency, however, then societal efficiency would be improved by diminishing or eliminating these claims. For example, if Title VII claims ultimately end up costing society more than they create in benefits, then society would be better off if Title VII claims were eliminated. The most direct way to do this, of course, would be to repeal Title VII. But less direct methods could also have an effect. If, as critics claim, predispute arbitration agreements are a way for employers to elude some of their Title VII liability, then such agreements are a method for diluting the inefficient effects of Title VII. The more biased the agreement, the better. By effectively acting as a waiver, biased predispute agreements could dilute or eliminate employment law liability and thereby improve societal efficiency.

Although I have not found any proponents of predispute arbitration who make this claim, one criticism of the current system

189 See infra notes 240-44 and accompanying text.

190 See supra notes 18-24 and accompanying text. 
of employment law litigation has been that the system is biased against employers and too permissive towards frivolous suits. ${ }^{191}$ If the system is too corrupt, it would arguably be inefficient to maintain it. However, certainly no courts have justified predispute arbitration on this basis; if anything, courts have stressed that arbitration should have little or no effect on the underlying resolution of employment law claims. ${ }^{192}$ Because this subject is beyond the scope of this analysis, I will leave it for other commentators. ${ }^{193}$

2. Reducing Societal Litigation Costs. This Article's model for pre and postdispute arbitration agreements has focused solely on the employee and the employer. ${ }^{194}$ And this Article has declared an agreement to be efficient if it maximizes the utility of the two parties. ${ }^{195}$ It has not, however, taken into account whether the two parties might create external costs that would lead to greater societal inefficiency but would be ignored by the parties themselves. In other words, do decisions to arbitrate or litigate create societal externalities? And do predispute arbitration agreements reduce or increase the incidence or significance of these externalities?

191 For example, David Sherwyn chastises critics of predispute arbitration who support the current system of litigation. Sherwyn, supra note 124, at 66. He states:

These critics do not, however, even acknowledge that under [sic] the current system may be unjust. They do not discuss the fact that merit is not the driving force in determining the resolution of a case. They do not mention that high cost of defense associated with litigation results in incidences of "de facto severance" and other forms of systemic leveraging to extort settlement for claims with no merit. These individuals may not care about employers' costs of defense or the fact that arbitration reduces incidence of "de facto severance" and other forms of systemic leveraging to extort settlement for claims with no merit.

Id. (internal citations omitted).

192 See EEOC v. Waffle House, Inc., 534 U.S. 279, 295 n.10 (2002) ("[F]ederal statutory claims may be the subject of arbitration agreements . . because the agreement only determines the choice of forum."); Gilmer v. Interstate/Johnson Lane Corp., 500 U.S. 20, 26 (1991) ("[B]y agreeing to arbitrate a statutory claim, a party does not forgo the substantive rights afforded by the statute; it only submits to their resolution in an arbitral, rather than a judicial, forum.") (quoting Mitsubishi Motors Corp. v. Soler Chrysler-Plymouth, Inc., 473 U.S. 614, 628 (1985)).

${ }_{193}$ For more on this issue, see John J. Donahue, III, Is Title VII Efficient?, 134 U. PA. L. REV. 1411 (1986), and Richard A. Posner, The Efficiency and Efficacy of Title VII, 136 U. PA. L. REV. 513 (1987).

194 See supra notes 25-70 and accompanying text.

195 See supra notes 36-37 and accompanying text. 
The most obvious externality created by a decision to litigate is the costs of running the judicial system. Although parties are obliged to pay filing fees, these minimal fees do not cover the costs of running the judicial system. Judges, clerks, court clerks, administrative staff, security personnel, and building maintenance staff must all be paid. ${ }^{196}$ Building construction or rental costs are incurred, as are costs for office supplies, computer systems, and the other standard necessities for a white-collar workplace. ${ }^{197}$ Juries must be selected and paid. The court systems (and thereby the taxpayers) absorb most of these costs, ${ }^{198}$ minus the small amount they receive in fees. These costs represent a significant additional set of burdens that society must shoulder in order to maintain the availability of litigation. If the parties choose arbitration, then the parties pay for these costs. Since the parties need not worry about the societal costs of litigation, they are apt to ignore them-creating an externality.

By way of example, let us return to the postdispute model. As noted, each party will choose arbitration over litigation if:

$$
P_{a} * R_{a}-C_{a}>P_{l} * R_{l}-C_{l}
$$

For purposes of making a simple example, assume that the employee has a $75 \%$ chance of winning $\$ 10,000$ both in litigation and arbitration. In arbitration, the costs would be $\$ 500$ for each party, but in litigation they would be $\$ 400$. Since the costs of litigation are lower than the costs of arbitration for each party, the parties would both choose litigation over arbitration. ${ }^{199}$

However, this model leaves out an important variable: the costs of litigation to society. Until this point, all costs in the model have been absorbed by the employee and the employer. Thus, what was

\footnotetext{
196 In 2002, Congress allocated a budget of $\$ 4.6$ billion to the federal judiciary. Leonidas Ralph Mecham, ANN. ReP. OF THE DiRECTOR, ADMIN. OFF. OF THE U.S. CTS. 8 (2002), available at http://www.uscourts.gov/library/dirrpt02/2002.pdf.

197 Since 1985 Congress has appropriated more than $\$ 5$ billion for courthouse construction. Id. at 2 .

198 Individual jurors also absorb the opportunity costs of whatever they would have done if they had not been selected for jury duty.

199 Expressed as an equation: $(.70 * \$ 10,000)-\$ 500=\$ 6,500<(.70 * \$ 10,000)-\$ 400=$ $\$ 6,600$.
} 
efficient for them jointly has been efficient for society as a whole. But the parties do not have to absorb all of the costs of litigating a case and, therefore, may not take them into account when deciding on the most efficient option. The parties would ultimately make their choice based on what is most efficient between them, represented by the equation:

$$
\text { - JC as compared with - JC }
$$

$J C$ is the joint costs of both parties. ${ }^{200}$ From society's standpoint, however, arbitration would be more efficient than litigation when the following equation is satisfied:

$$
-J C_{a}>-J C_{l}-S C_{l}
$$

In this equation, $S C_{l}$ represents the social costs of litigation. If $S C_{l}$ is greater than zero, then there may be some cases in which the parties will choose litigation when, from society's perspective, it would be more efficient for the parties to choose arbitration. Returning to the current example, let us assume that if the parties took the case to court, the court system would incur a cost of an additional $\$ 500$ processing the case and administering the trial. ${ }^{201}$ If we add the costs to both parties and the costs to the court system, arbitration clearly is more efficient. ${ }^{202}$ However, the parties do not absorb these costs and therefore would choose litigation. Their choice would be efficient as between the two of them but inefficient from a societal viewpoint.

Perhaps a view to societal efficiency is one reason many courts have been eager to uphold predispute arbitration agreements. After all, courts know better than anyone else the societal costs that litigation incurs. ${ }^{203}$ Instead of imagining yourself as an employee,

\footnotetext{
200 As noted in Part II.A., the parties will bargain to choose the most efficient result even if the parties have differing expenses for each process. See supra notes 37-42 and accompanying text.

${ }_{201}$ The expected cost of the litigation is $\$ 1,000$, since we would know ahead of time whether the case would get to trial.

${ }^{202}$ Arbitration's total costs would be $\$ 500+\$ 500=\$ 1,000$. Litigation's total costs would be $\$ 400+\$ 400+\$ 500=\$ 1,300$.

203 See Richard A. Posner, The Federal Courts: Challenge And Reform 237 (1996)
} 
imagine yourself as a federal judge. You know your docket has a substantial number of employment-related cases. These cases often revolve around questions of fact rather than questions of law, and the stakes are small compared with heady constitutional questions or complex business transactions. ${ }^{204}$ Along comes a new avenue for these claims - a method of dispute resolution that is familiar to judges from the union context. ${ }^{205}$ The parties-or often just the employer-absorb most of the costs of this new system. ${ }^{206}$ Theoretically, this system could be a cheaper and more accurate method of resolving difficult employment disputes, and the costs are borne directly by the litigants. From an efficiency (as well as an institutional) perspective, predispute agreements seem fairly attractive.

Of course, litigation costs are not purely dead weight. Most of the benefits from litigation are ex ante, in that the potential for litigation deters parties from engaging in illegal conduct. If an arbitration system failed to enforce a party's rights in the same manner as the judicial system, society would lose efficiency as illegal behavior increased. Just as the costs of litigation are compared with the costs of arbitration, the deterrent effects of litigation must be balanced against the deterrent effects of arbitration. If arbitration is too biased toward employers, such that employers feel more free to engage in prohibited activities or reduce their precautionary measures, societal costs from increased illegal activity will

("One substitute for federal judicial services is arbitration, so it is not surprising that the federal courts have become increasingly hospitable to arbitration."); Cole, supra note 9, at 449 ("Taking the task into their own hands, judges, in an attempt to reduce their workload without increasing costs or delays, have embraced arbitration as an alternate means for resolving disputes.").

204 See Harry T. Edwards, Where Are We Heading with Mandatory Arbitration of Statutory Claims in Employment?, 16 GA. ST. U. L. REV. 293, 306 ("These [cases founded on employment disputes] are often tedious cases, involving angry parties and mostly fact-bound disagreements. It is not the kind of litigation that most judges prefer to manage.").

${ }^{205}$ Arbitration has long been a staple in the union context, and the Supreme Court has upheld wide powers for arbitrators in the collective bargaining context, most notably in the Steelworkers Trilogy. United Steelworkers v. Enter. Wheel \& Car Co., 363 U.S. 593, 599 (1960); United Steelworkers v. Warrior \& Gulf Navigation Co., 363 U.S. 574, 582-83 (1960); United Steelworkers v. Am. Mfg. Co., 363 U.S. 564, 569 (1960).

206 An important issue in predispute arbitration agreements is whether the employer must bear the costs of the arbitration. See infra notes 229-40 and accompanying text. 
increase - and may overtake the institutional cost savings. ${ }^{207}$ Thus, if courts were attracted to arbitration as a method of increasing social efficiency, they would need to maintain a level of fairness for the arbitral process sufficient to keep a proper level of deterrence.

Some commentators have pointed to another potential cost of arbitration-the loss of judicial decisions on critical issues in the law. Arbitration agreements often keep the results of any particular arbitration a secret. Not all agreements require written decisions. For those that do, the parties may place restrictions on their own ability to publicize such opinions. As more disputes are diverted into arbitration, there will be fewer litigated cases and thus fewer published decisions. The end result will be a sparser and poorer legal landscape, where statutory rights remain stagnant and the law does not adapt to societal change. ${ }^{208}$ It is difficult to measure the costs and benefits from judicial decisions at a societal level. Certainly, such decisions have important benefits-they provide further explication and development of the law. Law without written opinions would be hard to fathom. And many of the employment laws-particularly the Americans with Disabilities Act-are relatively new and require a great deal of judicial exegesis. Judicial decisions, however, also have costs for both the parties and society. Settlement is generally considered the most efficient way of resolving a dispute. There may be some ratio of societal disputes to judicial opinions that maintains the optimal level of growth in the law, but I know of no research that has attempted to generate such a number. Moreover, the law would continue to develop even under a system where predispute arbitration agreements are enforced. Not all employers or employees will enter into predispute agreements. The EEOC can still bring suits on behalf of individual employees to assert the employees' federal employment law rights, even if those employees are covered by an arbitration agreement. ${ }^{209}$ Through its

\footnotetext{
207 Cf. Morrison v. Circuit City Stores, Inc., 317 F.3d 646, 658 (6th Cir. 2003) (noting that certain types of provisions may "undermine[ ] the deterrent effect of the antidiscrimination statutes").

208 See Owen M. Fiss, Against Settlement, 93 YALE L.J. 1073, 1085 (1984) (arguing that underlying purpose of litigation is to explicate common values and norms, which settlement does not do).

209 See EEOC v. Waffle House, Inc., 534 U.S. 279, 297 (2002) (holding EEOC claim not restricted by mandatory arbitration agreement).
} 
claim intake process, the EEOC can select those cases that raise novel issues of law and ensure that the issues receive a judicial hearing. ${ }^{210}$ Finally, if these mitigating factors are deemed insufficient, society could permit courts to review arbitration decisions that concern novel issues of law. ${ }^{211}$

Ultimately, I think the issue of societal efficiency presents the most persuasive argument for predispute arbitration. By enforcing predispute agreements, the courts have overseen the creation of a new system of dispute resolution paid for by the parties themselves. If the arbitral forum is truly as fair as its proponents submit, then society gets a cheaper form of adjudication without any corresponding loss in deterrence. Of course, whether predispute agreements are generally fair is still open to investigation. Given the potential for employer opportunism, I would hesitate to suggest such agreements are fair without substantial evidence.

\section{Thoughts on the NeXt Generation of DeBATE}

Critics of predispute arbitration agreements generally focus on the potential for unfair arbitration procedures. Unfair procedures such as the following may stack the deck against employees: Employees may have drastically shortened statutes of limitation, they may have to provide discovery from which the employer is exempt, employers may control the choice of arbitrators or the pool of potential arbitrators, and employers may provide themselves with rights of notice or appeal not provided to employees. ${ }^{212}$ Even with fair procedures, arbitration may arguably be tilted against employees if the arbitrators themselves are biased. According to some commentators, the repeat-player effect enables employers to have more familiarity with arbitrators, ${ }^{213}$ and arbitrators may

\footnotetext{
210 See Estreicher, supra note 129, at 1356 (noting that greater use of arbitration by individual employees frees up administrative agencies to pursue systemic litigation).

${ }^{211}$ For a suggestion in this regard, see Monica J. Washington, Note, Compulsory Arbitration of Statutory Employment Disputes: Judicial Review Without Judicial Reformation, 74 N.Y.U. L. REV. 844, 863 (1999).

${ }^{212}$ An arbitration agreement required by Hooters of America contained all of these. Hooters of Am., Inc. v. Phillips, 173 F.3d 933, 938-39 (4th Cir. 1999).

213 Robert A. Gorman, The Gilmer Decision and the Private Arbitration of Public Law Disputes, 1995 U. ILL. L. REV. 635, 656 (1995); see also Mark Berger, Can Employment Law
} 
consciously or unconsciously favor employers since employers administer and often pay for the arbitration system. ${ }^{214}$

Now that the Supreme Court has made clear that the FAA's provisions apply to almost all employees, ${ }^{215}$ state and lower federal courts have set about the task of defining the limits of acceptable arbitration procedures. But a fundamental question remains: How is that debate to be framed? Will it be framed primarily by contract law, which focuses on the voluntary agreement between the two parties? Or will courts find that arbitration procedures must have a certain level of procedural fairness in order to protect the deterrent and remedial purposes of the underlying statutes? The Supreme Court's Gilmer decision provides support for both perspectives. On the one hand, Gilmer cites the FAA for the proposition that arbitration agreements should be enforced "save upon such grounds as exist ... for the revocation of any contract." ${ }^{216}$ The Court noted that "fraud or overwhelming economic power" may justify contractual revocation but found such doctrines were not present in that case. ${ }^{217}$ On the other hand, Gilmer also makes clear that arbitration is only permissible if a party does not lose any substantive rights as a result of the agreement. ${ }^{218}$ The Court appears to require, as a condition of arbitration, that the "prospective litigant effectively may vindicate [his or her] statutory cause of action in the arbitral forum." 19 In this context, the Court reviewed several procedural provisions in the arbitration agreement, including those related to the selection of arbitrators and limitations on discovery and class actions. It held that there was "no showing"

Arbitration Work?, 61 UMKC L. REV. 693, 714 (1993) ("[S]ince employers rather than individual employees are more likely to have repeat participation in the employment dispute arbitration process, arbitrators are more likely to rule in their favor in order to increase their chances of being selected to arbitrate future claims."); Alleyne, supra note 10, at 426 (noting temptation for arbitrators to favor institutional employer interests).

214 Cole, supra note 9 , at 478 .

215 Circuit City Stores, Inc. v. Adams, 532 U.S. 105, 119 (2001) (interpreting FAA to exclude only workers directly involved in interstate transportation).

${ }^{216}$ Gilmer v. Interstate/Johnson Lane Corp., 500 U.S. 20, 33 (quoting 9 U.S.C. § 2 (2000)).

217 Id.

218 See id. at 26 ("By agreeing to arbitrate a statutory claim, a party does not forgo the substantive rights afforded by the statute; it only submits to their resolution in an arbitral, rather than a judicial, forum.'”) (quoting Mitsubishi Motors Corp. v. Soler Chrysler-Plymouth, Inc., 473 U.S. 614, 628 (1985)).

219 Id. at 28. 
that such procedures "[would] prove insufficient" for the vindication of the statutory claims. ${ }^{220}$ As one circuit court noted, this approach is necessary to prevent unfair agreements that "would enable employers to evade the requirements of federal law altogether."221 In a recent case concerning consumer arbitration, the Supreme Court discussed both perspectives as a joint test: "In determining whether statutory claims may be arbitrated, we first ask whether the parties agreed to submit their claims to arbitration, and then ask whether Congress has evinced an intention to preclude a waiver of judicial remedies for the statutory rights at issue." ${ }^{222}$

State and federal courts have considered both of these approaches in reviewing predispute employment arbitration agreements. In striking down arbitration agreements on contractual grounds, California and the Ninth Circuit (interpreting California law) have relied on the doctrine of unconscionability. ${ }^{223}$ In the Hooters case, the Fourth Circuit held that the arbitration agreement violated the duty of good faith and fair dealing. ${ }^{224}$ Some courts have discussed the doctrines of consideration and mutuality of obligation. ${ }^{225}$ However, courts have also looked to whether arbitration procedures are sufficiently fair to vindicate underlying substantive rights. For example, the D.C. Circuit in Cole v. Burns International Security Services ${ }^{226}$ upheld an arbitration agreement based on the procedural fairness of the agreement. The court set forth five procedural requirements for arbitral agreements, and found that the requirements were met in the instant case. ${ }^{227}$ Other courts have

220 Id. at $30-32$.

221 Morrison v. Circuit City Stores, Inc., 317 F.3d 646, 658 (6th Cir. 2003).

222 Green Tree Fin. Corp.-Alabama v. Randolph, 531 U.S. 79, 90 (2000).

223 Circuit City Stores, Inc. v. Adams, 279 F.3d 889, 892-93 (9th Cir. 2001); Armendariz v. Found. Health Psychcare Servs., 6 P.3d 669, 689 (Cal. 2000). Other courts have also discussed unconscionability in the context of employment arbitration agreements. See, e.g., Alexander v. Anthony Int'l, L.P., 341 F.3d 256, 270 (3d Cir. 2003) (finding thirty-day time limit, restrictions on relief, and "loser pays" provision to be unconscionable); Morrison, 317 F.3d at 666-67 (6th Cir. 2003) (finding the agreement not to be unconscionable); Wilcox v. Valero Ref. Co., 256 F. Supp. 2d 687, 691 (S.D. Tex. 2003) (finding application of arbitration agreement to conduct that happened before agreement not unconscionable).

224 Hooters of Am., Inc. v. Phillips, 173 F.3d 933, 940 (4th Cir. 1999).

225 E.g., Morrison, 317 F.3d at 667-68; Harris v. Green Tree Fin. Corp., 183 F.3d 173, 180 (3d Cir. 1999); Faber v. Menard, 267 F. Supp. 2d 961, 972 (N.D. Iowa 2003).

226105 F.3d 1465, 1482 (D.C. Cir. 1997).

227 Id. The court noted: 
employed a similar "effect-on-substantive-rights" analysis in reviewing certain arbitral procedures. ${ }^{228}$

One procedural issue that has been analyzed under both contractual and substantive-rights approaches is the cost-splitting provision in some arbitration agreements. Since the parties are paying for the entire costs of arbitration, those costs may reach significant levels. Although some employers offer to pay for the bulk of arbitration costs in their arbitration agreements, other employers require the costs of arbitration to be split between the parties. In Green Tree Financial Corp.-Alabama v. Randolph, ${ }^{229}$ the Supreme Court focused primarily on the substantive-rights analysis, recognizing that "the existence of large arbitration costs could preclude a litigant ... from effectively vindicating her federal statutory rights in the arbitral forum." 230 The Court, however, was unwilling to say that the possibility of such preclusion was enough to impair substantive rights. ${ }^{231}$ Ultimately, the Court adopted a case-by-case approach to this issue, holding that parties bear the burden of establishing that costs will be prohibitive. ${ }^{232}$

Lower courts have differed over whether such cost-splitting arrangements are enforceable. Some courts have held such

We believe that all of the factors addressed in Gilmer are satisfied here. In particular, we note that the arbitration arrangement (1) provides for neutral arbitrators, (2) provides for more than minimal discovery, (3) requires a written award, (4) provides for all of the types of relief that would otherwise be available in court, and (5) does not require employees to pay either unreasonable costs or any arbitrators' fees or expenses as a condition of access to the arbitration forum. Thus, an employee who is made to use arbitration as a condition of employment "effectively may vindicate [his or her] statutory cause of action in the arbitral forum." Id. at 1482 (alteration in original) (citation omitted).

228 See, e.g., Musnick v. King Motor Co., 325 F.3d 1255, 1259 (11th Cir. 2003) (concluding employee must arbitrate if he cannot prove fee-shifting prohibits exercise of federal statutory rights); DeOrnellas v. Aspen Square Mgmt., 295 F. Supp. 2d 753 (E.D. Mich. 2003) (holding cost-sharing provision of agreement invalid because of cost to substantive rights).

${ }^{229} 531$ U.S. 79, 90 (2000). Randolph concerned consumer, rather than employment, arbitration. Id. at 94 .

${ }^{230} I d$. at 90. The Court resolved the contract issue in a brief sentence. See id. ("In this case, it is undisputed that the parties agreed to arbitrate all claims relating to their contract, including claims involving statutory rights.").

${ }^{231}$ Id. at $90-91$.

${ }_{232}$ Id. at 92 ("Similarly, we believe that where, as here, a party seeks to invalidate an arbitration agreement on the ground that arbitration would be prohibitively expensive, that party bears the burden of showing the likelihood of incurring such costs."). 
agreements unenforceable on contractual grounds. The Ninth Circuit has held cost-splitting arrangements to be substantively unconscionable. ${ }^{233}$ Most courts, however, have followed Randolph's lead and analyzed such arrangements as a substantive-rights issue. Prior to Randolph, some courts suggested that cost splitting arrangements were per se unenforceable. ${ }^{234}$ After Randolph, courts have adopted the Court's case-by-case approach, asking claimants to prove that the costs of arbitration are "so substantial as to deter the bringing of claims." ${ }^{235}$ However, courts have differed on what kind of costs deter claims. ${ }^{236}$ One school of thought has held that any costs above and beyond those assessed as court costs and filing fees deter such claims and therefore affect substantive rights. ${ }^{237}$ Another approach favors an analysis of whether the costs are actually high enough to deter the bringing of claims. In this regard, the Sixth Circuit asks whether costs are potentially high enough to chill a class of potential litigants. ${ }^{238}$ The Fourth Circuit, on the other hand, inquires into whether the actual arbitral costs in a particular instance prevent the particular litigant from having an adequate and accessible substitute forum. ${ }^{239}$ These fractured approaches have

\footnotetext{
233 See Ferguson v. Countrywide Credit Indus., Inc., 298 F.3d 778, 785 (9th Cir. 2002) (holding that "a fee allocation scheme which requires the employee to split the arbitrator's fees with the employer would alone render an arbitration agreement substantively unconscionable").

234 E.g., Shankle v. B-G Maint. Mgmt. of Colo., Inc., 163 F.3d 1230, 1235 (10th Cir. 1999); Cole, 105 F.3d at 1485 .

${ }^{235}$ Bradford v. Rockwell Semiconductor Sys., Inc., 238 F.3d 549, 556 (4th Cir. 2001).

236 See Michael H. Leroy \& Peter Feuille, When Is Cost an Unlawful Barrier to Alternative Dispute Resolution? The Ever Green Tree of Mandatory Employment Arbitration, 50 UCLA L. REV. 143, 180-89 (2002) (discussing these positions in terms of "forum substitution" school versus "comparative cost of litigation" school).

${ }^{237}$ See Armendariz v. Found. Health Psychcare Servs., Inc., 3 P.3d 669, 687 (Cal. 2000). Accordingly, consistent with the majority of jurisdictions to consider this issue, we conclude that when an employer imposes mandatory arbitration as a condition of employment, the arbitration agreement or arbitration process cannot generally require the employee to bear any type of expense that the employee would not be required to bear if he or she were free to

$I d$. bring the action in court.

238 See Morrison v. Circuit City Stores, Inc., 317 F.3d 646, 663 (6th Cir. 2003) (noting that inquiry into typical "job description and socioeconomic background" of potential litigant should be undertaken).

239 See Bradford, 238 F.3d at 556.

We believe that the appropriate inquiry is one that evaluates whether the
} 
led to divergent results. An empirical study of reported cases on the issue found that appellate courts ordered arbitration in only half of the cases in which claimants contested cost-splitting arrangements. $^{240}$

The framing of the analysis concerning these procedural issues will have a profound effect on how these issues are determined. If they are scrutinized under the lens of contract law, the primary issue will be whether these parties reached a free and voluntary agreement to arbitrate under the specified circumstances. If they are examined for their effects on substantive rights, the issue becomes the actual impact of the particular procedure on the underlying arbitration. There are reductive perils to either approach. Analyzed as a contract law issue, if the parties have in fact both agreed to the arbitration contract, the effects of the actual procedures-no matter how draconian-would appear meaningless. On the other hand, arbitral procedures of necessity have an impact on the underlying adjudication; in fact, the parties have theoretically chosen arbitration to take advantage of those procedures. Thus, the question of "effect" is too simple. Determining whether a particular procedure has a certain level of effect on substantive rights_-"substantial" effect, perhaps, or "preclusive" effect-is an exercise that is ultimately more about a court's view on the merits of arbitration.

My hope is that the model set forth in Part $\mathrm{II}^{241}$ will provide a new basis for courts and commentators to analyze the contractual issues surrounding predispute arbitration agreements. The complexity of the model calls into question whether such agreements are based on adequate cost-benefit analyses. It seems likely that employees cannot make such analyses and instead fall back onto

\footnotetext{
arbitral forum in a particular case is an adequate and accessible substitute to litigation, i.e., a case-by-case analysis that focuses, among other things, upon the claimant's ability to pay the arbitration fees and costs, the expected cost differential between arbitration and litigation in court, and whether that cost differential is so substantial as to deter the bringing of claims.

$I d$.

${ }_{240}$ Leroy \& Feuille, supra note 236, at 177. District courts, however, ordered arbitration in $77 \%$ of cases in which cost was raised as an issue. Id.

${ }^{241}$ See supra notes 47-70 and accompanying text.
} 
decisionmaking heuristics in agreeing to arbitration. Thus, the fact that both parties have "agreed" to the provision does not mean both parties have arrived at a meaningful decision that the provision will make them better off. Once this uncertainty has been acknowledged, we may then move to the next round of scrutiny: whether such agreements should be enforced. As mentioned earlier, imperfections in the bargaining process do not require that a contract be held unenforceable. However, the information gap in the predispute context provides a significant reason for subjecting predispute agreements to an unconscionability analysis. Interestingly, courts that find such agreements to be unconscionable have not focused on the information gap but have instead relied on such concepts as "unequal bargaining power" and "contracts of adhesion." 242 A deeper understanding of the information gap would make these terms less of a placeholder and provide stronger grounds for a finding of unconscionability. ${ }^{243}$

Moreover, the existence of the information gap points to two directions for future reforms of the arbitration process. One direction would involve greater scrutiny by courts of the terms of each agreement for its procedural fairness. Given the information gap, this ongoing scrutiny makes sense because employees have not had the wherewithal to police such terms themselves. Moreover, standard requirements for arbitration agreements would reduce the information necessary to evaluate each agreement, since employees would know that the agreement would at least have to adhere to a certain level of fairness. A second direction, however, would be to

\footnotetext{
242 Alexander v. Anthony Int'l, L.P., 341 F.3d 256, 264-66, 270 (3d Cir. 2003); Ferguson v. Countrywide Credit Indus., Inc., 298 F.3d 778, 784 (9th Cir. 2002).

${ }^{243}$ Cf. Russell Korobkin, Bounded Rationality, Standard Form Contracts, and Unconscionability, 70 U. CHI. L. REV. 1203, 1206-07 (2002) (suggesting that unconscionability be used to prevent purveyors of adhesive contracts from taking advantage of market failure inherent in certain contracts relating to "salience" of particular contract term). Korobkin argues that buyers make their purchases based on a calculation of the salient costs and benefits of the decision but fail to account for nonsalient terms. Id. at 1243-44. Thus, sellers have an incentive to make nonsalient terms inefficiently favorable to themselves. Id. This approach has applications in the employment law context. Employees, like buyers, will make their employment choice based on the salient features of the job, such as salary, health benefits, job duties, and possibilities for promotion. The issue of employment arbitration is likely to be nonsalient, thus giving employers an opportunity to make such agreements inefficiently favorable. Cf. $i d$. at 1234 (discussing nonsalience of arbitration provisions in consumer agreements).
} 
require that more information be generated about the arbitral process. Requiring published arbitral opinions, for example, would allow employees greater access to information about the quality of the arbitral forum. The "win rates" for employers and employees for a particular arbitrator might also be useful information in evaluating potential bias. ${ }^{244}$ Perhaps employers might be required to provide a copy of arbitration rules and procedures or their own success rates in arbitration. Information about claims filed against the employer would provide employees with a sense of their risk of needing to file such a claim. As more information becomes available to employees, employers, and the counsel who work with each, the parties will have a better sense of the costs and benefits of arbitration and the wisdom of agreeing to arbitrate employment claims.

There are dangers to both mandatory procedures and greater disclosure. Arbitration is attractive in part due to its flexibility and adaptability to particular environments. Mandatory terms would restrict the parties' ability to develop a system of arbitration tailored to their needs. Similarly, greater disclosure would entail higher arbitral costs, as arbitrators and employers would need to develop and publish this information. When balanced against the costs of unfair arbitration agreements, however, these potential dangers may constitute a better alternative. Ultimately, we can hope that employers and employees will be able to engage in meaningful negotiations over arbitration agreements that are societally efficient and benefit both parties. But we are not there yet.

\section{CONCLUSION}

If the ideology behind law and economics is about freeing people to make rational decisions about their own utility, then it would be in line with this ideology-perhaps counterintuitively-to hold predispute employment arbitration agreements unenforceable. As I believe the foregoing models have demonstrated, employees are in

${ }^{244}$ Lisa B. Bingham, Employment Arbitration: The Repeat Player Effect, 1 EMPLOYEE RTS. \& EMP. POL’Y J. 189, 216-17 (1997) (discussing potential for disclosure concerning arbitrator bias). 
a much better position to judge the efficiency of arbitration and litigation after a dispute has arisen. Locking in employees ahead of time restrains their ability to make informed decisions. To justify predispute arbitration agreements, there should be a reason for employees to be locked in. Merely showing that arbitration in and of itself is cheap and fair does not explain why parties cannot choose it after the dispute has arisen.

There is a story to tell, however, about how predispute arbitration agreements may end up increasing societal efficiency. By shuttling parties into a (theoretically) quicker and cheaper form of dispute resolution, society may save money on judicial administration and litigation costs. Requiring the parties to pay for their own dispute resolution provides them with an incentive to keep costs down. And if we expect employers to pick up the bulk of this sum, as some courts have suggested, then allowing employers to lock all of their employees into a predispute arbitration system might be the only way for employers to recoup the costs of creating the system. It would be up to courts to require a combination of mandatory procedures and disclosures that would allow employers and employees to make informed, efficient decisions about such agreements. But in the meantime, society needs to recognize that employees do not have the informational resources to make accurate efficiency decisions about predispute arbitration agreements. 